Aus der Klinik für Hämatologie und Medizinische Onkologie

(Prof. Dr. med. L. Trümper)

der Medizinischen Fakultät der Universität Göttingen

\title{
EINFLUSS VON LEF1 AUF DAS TUMORWACHSTUM IM BURKITT-LYMPHOM-XENOGRAFT-MODELL
}

\author{
INAUGURAL-DISSERTATION \\ zur Erlangung des Doktorgrades \\ der Medizinischen Fakultät der \\ Georg-August-Universität zu Göttingen
}

vorgelegt von

Stefan Ueberdiek

aus Dresden

Göttingen 2016 
Dekan:

I. Berichterstatter:

II. Berichterstatter/in:

III. Berichterstatter/in:

Tag der mündlichen Prüfung: 27.10.2016
Prof. Dr. rer. nat. H.K. Kroemer

Prof. Dr. rer. nat. D. Kube

Prof. Dr. J. Wilting

Prof. Dr. T. Meyer 


\section{Inhaltsverzeichnis}

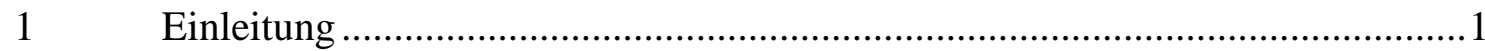

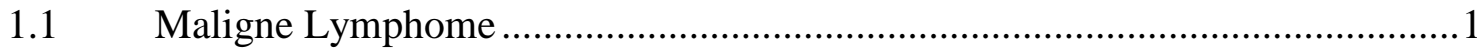

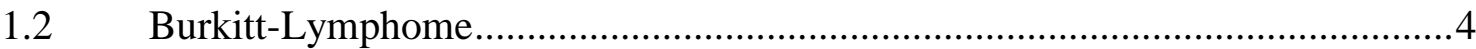

1.3 Der kanonische Wnt-Signalweg und die Rolle von LEF1 bei der Regulation von zellulären Funktionen.............................................................................

1.4 Das Xenograft-Tumor-Modell Chorioallantois-Membran-Assay (CAM-Assay)7

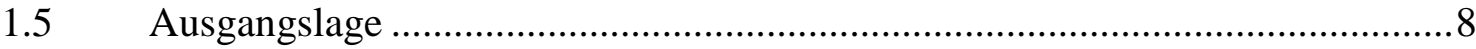

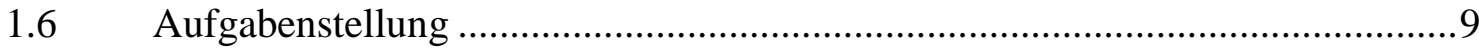

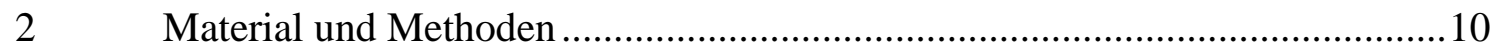

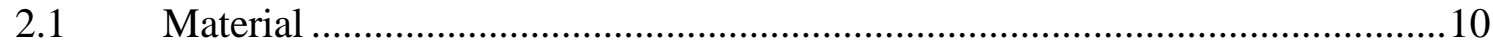

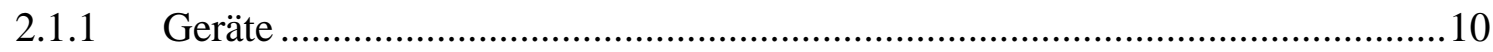

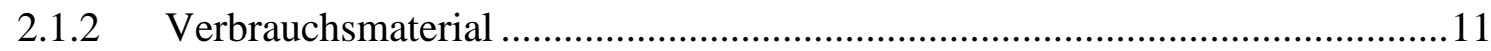

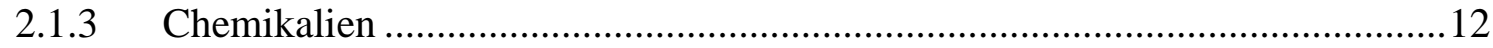

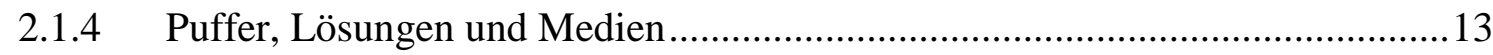

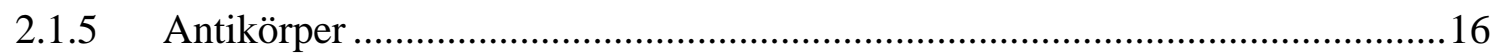

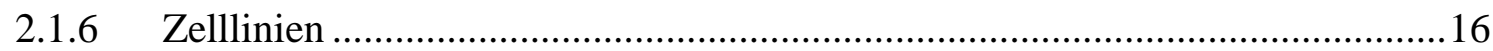

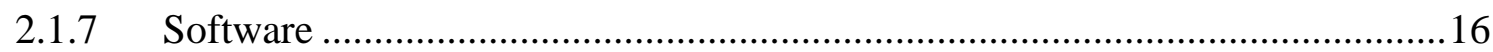

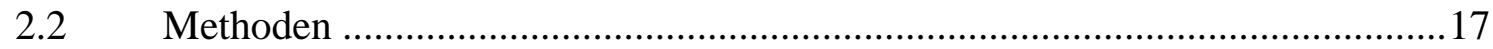

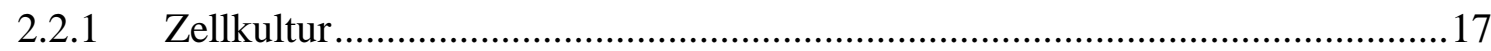

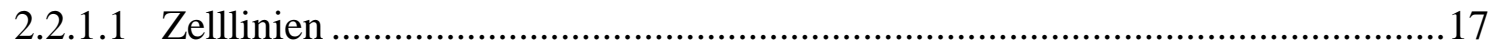

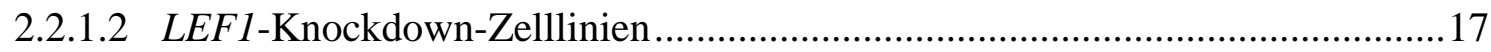

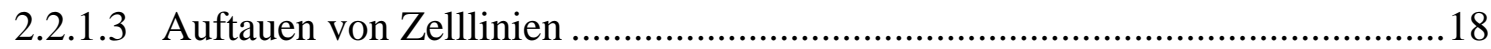

2.2.1.4 Zellzahl -und Viabilitätsbestimmung ........................................................... 18

2.2.1.5 Konservierung in Kryoröhrchen ................................................................. 19

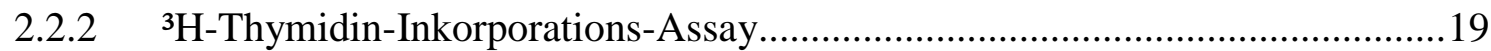

2.2.3 Durchflusszytometrie (FACS-Analyse) ....................................................... 19

2.2.4 Proteinbiochemische Methoden ...........................................................................20

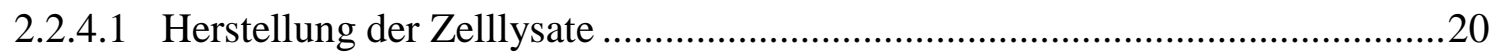

2.2.4.2 Bestimmung der Proteinkonzentrationen .....................................................2 21

2.2.4.3 SDS-Polyacrylamid-Gelelektrophorese (SDS-PAGE) ....................................21

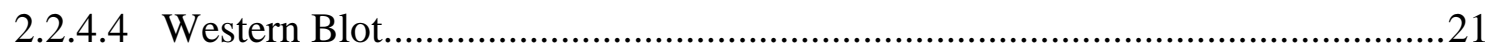

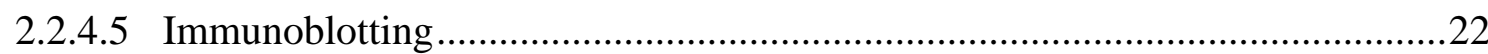

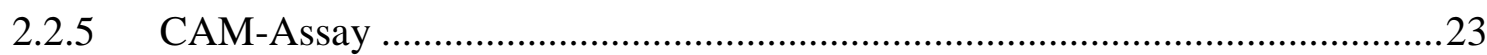

2.2.5.1 Beginn des Bebrütens/Start der Embryonalentwicklung ................................23 


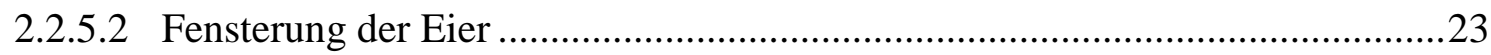

2.2.5.3 Beimpfung der CAM mit den BL2-Zellen.....................................................24

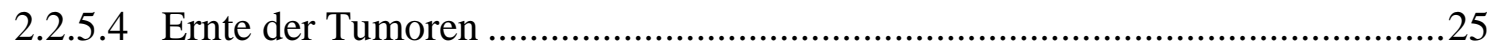

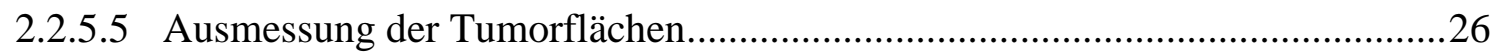

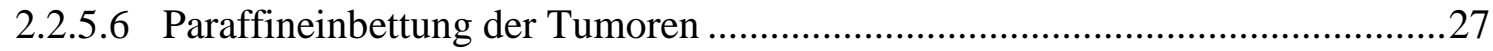

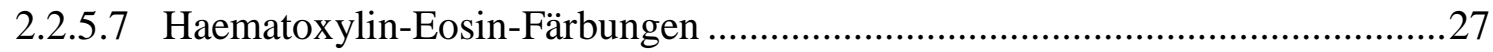

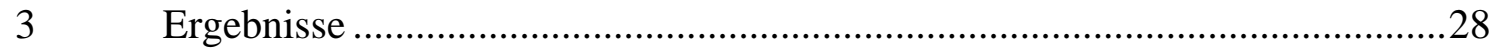

3.1 Charakterisierung von BL2-Zellen nach LEF1-Knockdown..........................28

3.2 Einfluss von LEF1 auf das Tumorwachstum im Xenograft-Modell.................30

3.2.1 LEF1-defiziente Xenograft-Tumoren sind kleiner als LEF1-aberrante Tumoren31

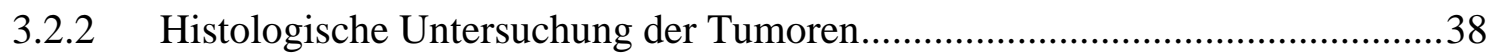

3.2.2.1 Histologie bestätigt Flächenunterschiede zwischen LEF1-aberranten und LEF1defizienten Lymphomen.............................................................................. 38

3.2.2.2 LEF1-defiziente Tumoren zeigen gehemmte Infiltration der CAM ................42

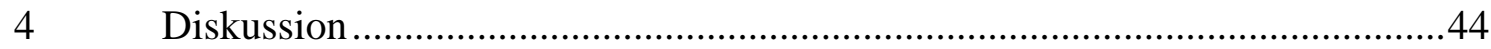

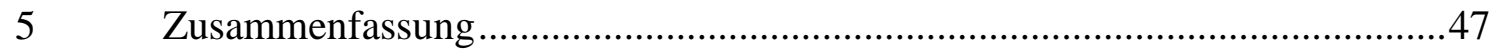

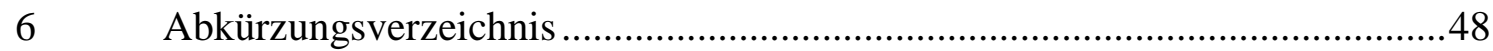

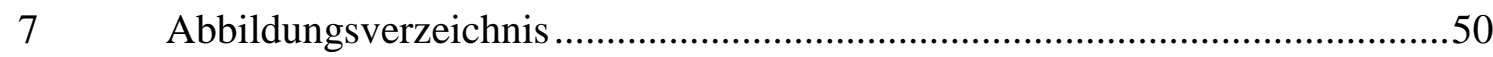

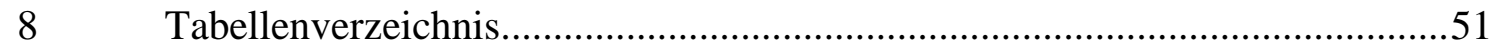

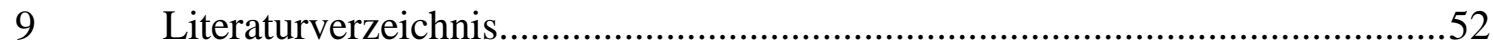

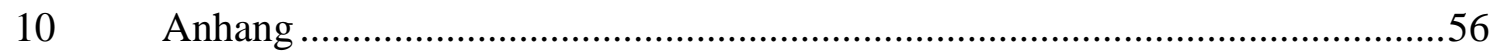

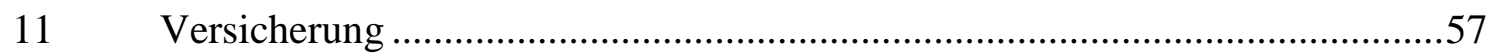

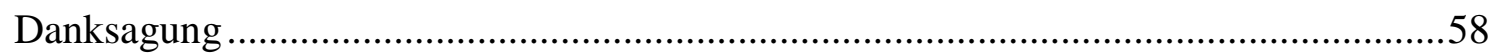

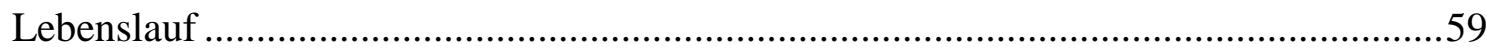




\section{$1 \quad$ Einleitung}

Krebserkrankungen sind nach kardiovaskulären Erkrankungen die zweithäufigste Todesursache in den entwickelten Ländern (Husmann et al. 2010). Die Neuerkrankungsrate der meisten Krebsarten wächst stetig, was vor allem durch die steigende Lebenserwartung der Menschen zu begründen ist, denn die Wahrscheinlichkeit der Krebsentstehung nimmt mit den Lebensjahren zu (Husmann et al. 2010). So beläuft sich die Zahl der über 80-jährigen Krebspatienten auf das 200 bis 300fache im Vergleich zu den unter 15-jährigen Krebspatienten (Husmann et al, 2010). Krebserkrankungen sind bösartige (maligne) Entartungen körpereigener Zellen. $\mathrm{Zu}$ den besonderen Charakteristika der Krebszellen zählen neben dem infiltrativen destruierenden Wachstum die Fähigkeit, Töchtergeschwülste (Metastasen) auch an entfernten Körperpartien bilden zu können (Hanahan et al, 2000). Nach heutigem Verständnis beruht die Krebsentstehung vor allem auf Mutationen, die krebswachstumsfördernde Gene (ProtoOnkogene) betreffen und somit zur gesteigerten Zellproliferation führen. Aber auch Mutationen in Genen, die unter normalen Voraussetzungen die Krebsentstehung hemmen (Tumorsuppressorgene), können zur Krebsentstehung führen (Hanahan et al, 2000). Die in dieser Arbeit behandelten Non-Hodgkin-Lymphome (NHL) stellen eine Krebsart dar, die den weißen Blutkörperchen (Leukozyten) und damit dem blutbildenden System entspringt. Trotz wachsender Erkenntnisse aus der Forschung und verbesserten diagnostischen und therapeutischen Ansätzen gibt es immer noch viele Patienten, die keine komplette Remission erreichen und folglich ein Rezidiv erleiden. Deshalb ist es umso wichtiger, an der Verbesserung der Therapiemöglichkeiten der Non-Hodgkin-Lymphome zu arbeiten.

\subsection{Maligne Lymphome}

Bei malignen Lymphomen handelt es sich um bösartige Neoplasien des lymphatischen Systems (Baenkler et al, 2008). Zur Einteilung wird die „WHO-Klassifikation von lymphatischen und hämatopoetischen Neoplasien“ herangezogen, die zuletzt 2008 aktualisiert wurde (WHO 2008). Danach richtet sich die Einteilung vor allem danach, ob sich die Tumorzellen von frühen Vorläufer- oder reifen Zellen der Hämatopoese ableiten (Dürkop et al, 2011). Zudem wird zwischen Hodgkin-Lymphomen (Morbus Hodgkin) und Non-Hodgkin-Lymphomen (NHL) unterschieden (Baenkler et al, 2008), wobei beide Lymphomarten als niedrig- und hochmaligne Entitäten ausgeprägt sein können (Baenkler et al, 2008). Ein NHL kann sich von B- oder TLymphozyten ableiten, während in Europa die meisten dieser Lymphome den B-Lymphozyten entspringen (Gerok et al, 2007). Die Inzidenz der Non-Hodgkin-Lymphome liegt bei 10- 
15:100.000/Jahr. Sie machen damit 6\% aller malignen Erkrankungen aus (Baenkler et al, 2008). Das mittlere Erkrankungsalter der NHL beträgt bei Männern 70 Jahre und bei Frauen 67 Jahre (Husmann et al, 2010). Ob ein NHL ein aggressives, schnell-proliferierendes oder ein indolentes, langsam-proliferierendes Wachstumsmuster aufzeigt, hängt unter anderem davon ab, welchen Vorläuferzellen es entspringt (Baenkler et al, 2008). Das Diffus großzellige BZell-Lymphom (DLBCL) macht mit 30-40\% aller NHL den größten Anteil der aggressiven NHL aus (Baenkler et al, 2008). Das Burkitt-Lymphom (BL) zählt zu den hoch aggressiven NHL und macht etwa 1-2\% aller Lymphome aus (Baenkler et al, 2008). Sehr häufige Frühsymptome der NHL sind schmerzlose Lymphknotenvergrößerungen, die durch Vermehrung von Lymphozyten oder der malignen Lymphomzellen entstehen (Baenkler et al, 2008). Oftmals ist beim Patienten eine sogenannte B-Symptomatik in der Anamnese zu eruieren, die durch Fieber, Nachtschweiß und Gewichtsverlust charakterisiert ist (näheres s. Tab. 1-1) (Baenkler et al, 2008). In vielen Fällen bemerkt der Patient nur geringe und sehr unspezifische Symptome wie eine erhöhte Infektanfälligkeit, Müdigkeit, Appetitlosigkeit, Übelkeit und/oder Sodbrennen (Baenkler et al, 2008). In 40-60\% der Fälle kommt es zur Infiltration des Knochenmarks (Kompetenznetz Maligne Lymphome 2014). Der Morbus Hodgkin (Inzidenz: 3:100.000/Jahr) leitet sich von B-Lymphozyten ab und weist histologisch charakteristischerweise Hodgkin- und Sternberg-Reed-Zellen auf (Dempke, 2006). Des Weiteren gibt es die Klassifikation maligner Lymphome nach Ann-Arbor (siehe Tab 1-1). Sie erfasst zum einen Erkrankungsstadium, möglichen extranodalen Befall sowie die Allgemeinsymptomatik (Baenkler et al, 2008; Herold 2014). 
Tab. 1-1: Klassifikation maligner Lymphome nach Ann-Arbor

\begin{tabular}{|c|c|}
\hline Stadium I & $\begin{array}{l}\text { Befall einer Lymphknotenregion oder Vorliegen eines extranodalen } \\
\text { Herdes }\end{array}$ \\
\hline Stadium II & $\begin{array}{ll}\text { - } & \text { Befall von } \geq 2 \text { Lymphknotenregionen auf einer Seite des } \\
\text { Zwerchfells oder } \\
\text { - } \quad \text { Befall eines extralymphatischen Gewebes plus einer oder } \\
\text { mehrerer Lymphknotenregionen auf einer Seite des Zwerchfells }\end{array}$ \\
\hline Stadium III & $\begin{array}{ll}\text { - } & \text { Befall von } \geq 2 \text { Lymphknotenregionen beiderseits des } \\
\text { Zwerchfells oder } \\
\text { - } \quad \text { Befall lokalisierter extranodaler Herde und Lymphknoten } \\
\text { beiderseits des Zwerchfells }\end{array}$ \\
\hline Stadium IV & $\begin{array}{l}\text { disseminierter Befall eines oder mehrerer Organe (z.B. Leber, } \\
\text { Knochenmark) mit oder ohne gleichzeitigen Lymphknotenbefall }\end{array}$ \\
\hline A & Keine Allgemeinsymptomatik \\
\hline B & $\begin{array}{l}\text { Fieber }\left(>38^{\circ} \mathrm{C} \text {, nicht anderweitig erklärbar) und / oder Nachtschweiß }\right. \\
\text { und / oder Gewichtsverlust (> } 10 \% \text { des Körpergewichts in den letzten } \\
6 \text { Monaten) }\end{array}$ \\
\hline $\mathrm{E}$ & Extranodaler Befall (z.B. Befall der Lunge, Niere, Haut) \\
\hline
\end{tabular}

Für die Therapie wird im klinischen Alltag in erster Linie das entsprechende NHL nach WHOKlassifikation bestimmt. Des Weiteren werden die Patienten nach den Risikofaktoren des International Prognostic Index (IPI) eingeteilt. Der IPI berücksichtigt die Faktoren Alter, Krankheitsstadium nach Ann Arbor, Anzahl der Extranodalbefälle, Performance-Status der Eastern Cooperative Oncology Group (ECOG) sowie die Serum-Laktat-Dehydrogenase (LDH). Therapiert wird mit einer Polychemotherapie gemäß dem CHOP- bzw. CHOEPSchema (Cyclophosphamid, Doxorubicin, Vincristin, ggf. Etoposid, Prednison). In Kombination kann mit dem humanisierten monoklonalen Antikörper Rituximab behandelt werden, welcher an das Transmembran-Antigen CD20 auf prä-B- und reifen B-Lymphozyten sowie die entsprechenden neoplastischen Zellen bindet. Niedrigmaligne NHL liegen bei Diagnosestellung in vielen Fällen bereits disseminiert vor (Baenkler et al, 2008). In den Stadien III und VI ist somit auch nur noch in den seltensten Fällen eine Heilung möglich (Baenkler et 
$a l, 2008)$. In den Stadien I und II erfolgt eine Radiotherapie mit kurativem Ansatz (Baenkler $e t$ $a l, 2008)$. Bei rezidivierenden hochmalignen NHL kommt eine Stammzelltransplantation in Betracht (Baenkler et al, 2008). Abhängig von Alter, Geschlecht und Subtyp beträgt die 5Jahres-Überlebensrate je nach Publikation zwischen 30 und $80 \%$ bei den NHL und ist damit deutlich schlechter als beim Hodgkin-Lymphom (Husmann et al, 2010; Pfreundschuh et al, 2004 a und b).

\subsection{Burkitt-Lymphome}

Das Burkitt-Lymphom wurde 1958 von Denis Burkitt zum ersten Mal beschrieben (Burkitt, 1958). Unterschieden werden zwei Formen, das endemische BL und das sporadische BL, das vor allem in Westeuropa auftritt und bevorzugt Erwachsene befällt (Baenkler et al, 2008). Über 90\% der endemischen BL und etwa 50\% der sporadischen BL sind mit dem Epstein-Barr-Virus (EBV) assoziiert (Maruo et al, 2001). Eine dritte Variante des BL wird in Verbindung mit dem Humanen Immundefizienz-Virus (HIV) beziehungsweise einer therapeutisch bedingten Immundefizienz gebracht (Tiemann und Trümper 2001). Das mittlere Erkrankungsalter des BL liegt bei 65 Jahren, wobei es einen ersten Gipfel im ersten Lebensjahrzehnt gibt, der dadurch zu erklären ist, dass es sich bei dem endemischen BL um einen eher kindlichen Tumor handelt (Dempke, 2006). Männer sind etwas häufiger betroffen als Frauen (1,7:1) (Dempke, 2006). Die entarteten B-Lymphozyten des BL entspringen den Lymphfollikelkeimzentren der Lymphknoten und manifestieren sich überwiegend extranodal (Stein und Hummel 2007). In über 90\% der Fälle des BL lässt sich eine Translokation zwischen den Chromosomen 8 und 14 [t(8;14)] nachweisen, die zu einer verstärkten Expression des Protoonkogens c-Myc führt und dadurch zu der Entstehung des Lymphoms beiträgt (Baenkler et al, 2008; Klein und DallaFavera 2008). In Deutschland macht das BL nur 4\% aller NHL aus (Kompetenznetz Maligne Lymphome 2014). Wegen seiner sehr zügigen Proliferation mit einer Verdopplungszeit von etwa $24 \mathrm{~h}$ wird das BL mit hochdosierten Chemotherapeutika in Kombination mit zytostatischen Mitteln wie dem monoklonalen Antikörper Rituximab (Empfehlung) behandelt (Baenkler et al, 2008; Hoelzer et al, 1996). So wird derzeit eine Remission bei etwa 85\% der Patienten und ein Langzeitüberleben bei etwa 70\% der Patienten erreicht (Baenkler et al, 2008). 


\subsection{Der kanonische Wnt-Signalweg und die Rolle von LEF1 bei der Regulation von zellulären Funktionen}

Der kanonische Wnt-Signalweg („Wnt“ Zusammensetzung aus wingless und INT-1) stellt neben den zwei nicht-kanonischen Wnt-Signalwegen, dem PCP (planar cell polarity)Signalweg und dem Wnt/Ca2+-Signalweg, einen der Wnt-Signalwege dar. Das Glykoprotein Wnt ist ein interzelluläres Signalmolekül, das den kanonischen Wnt-Signalweg stimulieren kann (Rassow et al, 2012). In der Embryonalentwicklung spielt der kanonische Wnt-Signalweg eine wichtige Rolle bei der Steuerung von Differenzierungswegen (Rassow et al, 2012). Er kann bei Erwachsenen zudem die Proliferation von Zellen auslösen (Rassow et al, 2012). Eine weitere zentrale Aufgabe in diesem Signalweg spielt das Protein ß-Catenin, das als Koaktivator von Transkriptionsfaktoren angesehen wird (Rassow et al, 2012). Solange Wnt seine Aufgabe als Ligand nicht wahrnimmt, liegt $\beta$-Catenin zytoplasmatisch in geringer Konzentration vor, da es als phosphoryliertes Protein dem Abbau im Proteasom zugeführt wird (Rassow et al, 2012). Bindet Wnt allerdings seinen Rezeptor Frizzled und den LRP (LDL-Rezeptor-ähnlichesProtein)-Korezeptor (siehe Abb. 1-1), bewirkt dies, dass das Protein Dishevelled phosphoryliert und dadurch aktiviert wird (Rassow et al, 2012). Dishevelled wiederum hat eine hemmende Wirkung auf die Kinase GSK-3ß (Glykogensynthase-Kinase 3ß), die sonst ß-Catenin phosphorylieren würde (Rassow et al, 2012). Daraufhin kann B-Catenin in den Zellkern wandern (Rassow et al, 2012). Neben der Diffusion von ß-Catenin in den Nukleus (passiv) spielt auch der aktive Transport von B-Catenin aus dem Zytosol in den Nukleus mittels Transportproteinen eine wichtige Rolle (Tan et al, 2014).

Im Zellkern dient B-Catenin dann als Koaktivator der Transkriptionsfaktoren der TCF/LEFFamilie (T Cell Factor) (Rassow et al, 2012). Der lymphocyte enhancer-binding factor-1 (LEF1) stellt ein Mitglied dieser Familie dar und kodiert für ein 48-kDa großes Protein, das auch physiologischerweise in prä-B und T-Lymphozyten exprimiert wird (Travis et al, 1991; Reya et al, 2000). Insgesamt sind aus dieser Familie beim Menschen neben LEF1 noch TCF-1, TCF-3 und TCF-4 bekannt, die unter anderem in den Wnt-Signalweg involviert sind. LEF1 spielt eine entscheidende Rolle in der Embryogenese und der Krebsentstehung, aber auch bei der Regulation von zellulären Funktionen wie Gentranskription, Apoptose und Zellproliferation (Wnt-Signalweg) (Gao et al, 2008; Hoeppner et al, 2011; Shelton et al, 2012). Für die BZellentwicklung im Speziellen ist LEF1 wichtig. Mehrere Studien deuten darauf hin, dass LEF1 eine Rolle bei der Transformation hämatopoetischer Zellen spielt (Van Den Berg et al, 1998; Rattis et al, 2004; Blank et al, 2008). Dereguliertes LEF1 spielt auch eine Rolle bei hämatoonkologischen Erkrankungen wie beispielsweise der B-Zell-CLL oder der B-Zell-ALL 
(Lu et al, 2004; Mullighan et al, 2007). In BL wird LEF1 aberrant exprimiert, nicht aber in DLBCL oder Mantelzell-Lymphomen (Hummel et al, 2006). Somit gehört LEF1 zu den 58 Genen, die den Burkitt-Index und seine molekularen Signaturen definieren und somit die Abgrenzung des BL zu anderen aggressiven Lymphomen ermöglichen (Hummel et al, 2006; Walther et al, 2013). Auch in BL-Zelllinien sind viele LEF1-Zielgene identifiziert, die interessanterweise eine hohe Assoziation zu bekannten Krebsgenen zeigen (Hummel et al, 2006; Walther et al, 2013). Unbekannt ist jedoch immer noch die biologische Wirkung von aberrantem LEF1 im BL (Walther et al, 2013).

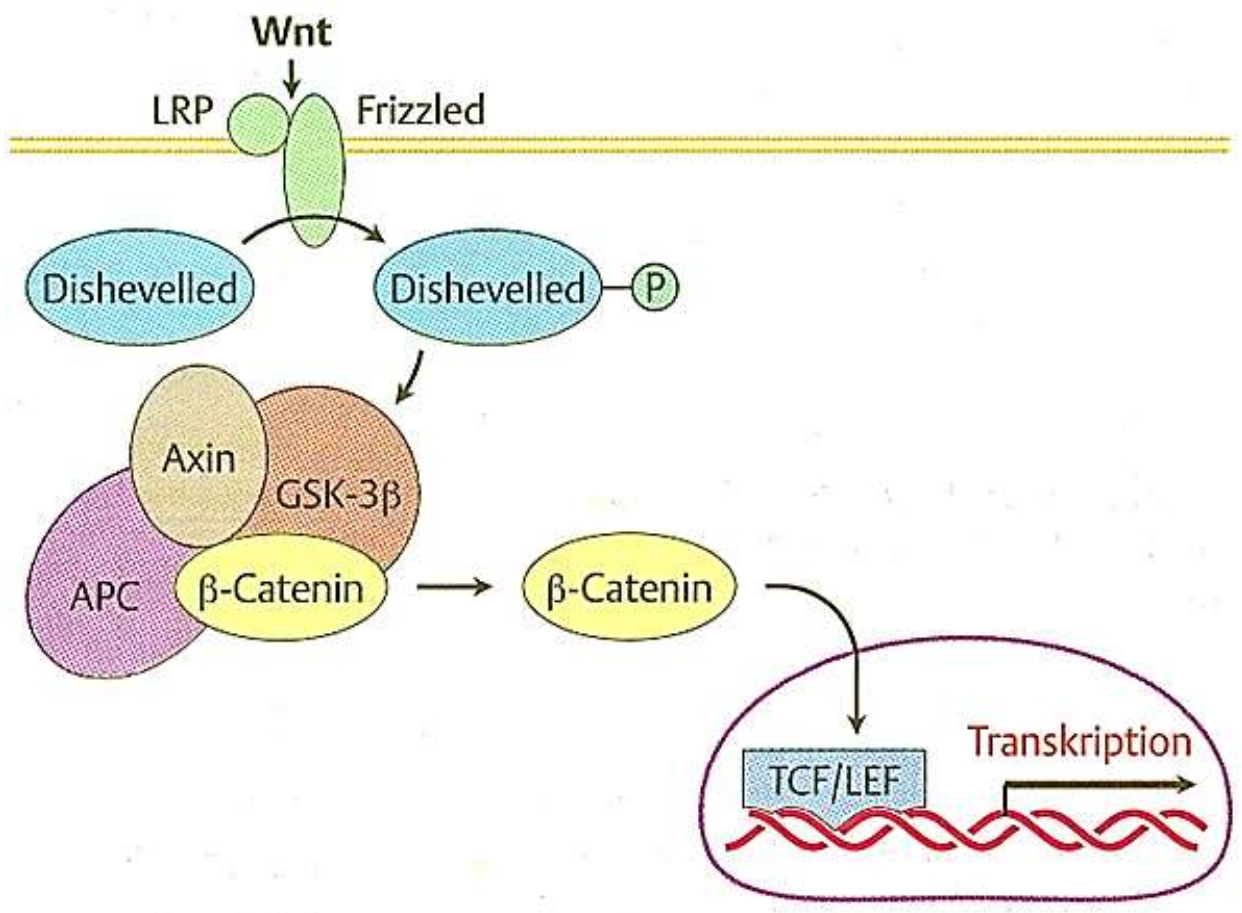

Abb. 1-1: Schematische Darstellung zentraler Elemente des kanonischen Wnt-Signalweg (aus: Rassow et al, 2012). Abkürzungen: Wnt- Wingless + INT-1; LRP- Low density lipoprotein receptorrelated protein; TCF: T Cell Factor, LEF- Lymphocyte enhancer-binding factor, APC- Adenomatouspolyposis-coli 


\subsection{Das Xenograft-Tumor-Modell Chorioallantois-Membran-Assay (CAM-Assay)}

Seit Beginn der Verwendung von Hühnerembryo-Modellen haben sich diese als sehr hilfreich erwiesen, um neue Erkenntnisse über Tumorentwicklung, -ausbreitung und -angiogenese zu erlangen (Murphy, 1913, Deryugina \& Quigley, 2008b). Diese Modelle zählen zu den Xenograft-Modellen, bei denen lebens- oder funktionstüchtige Zellen oder Zellverbänden zwischen verschiedenen Spezies zusammengebracht werden. Auf den Hühnerembryo bezogen spielen Untersuchungen bezüglich der Chorioallantois-Membran (CAM) die wichtigste Rolle. Physiologischerweise dient diese extraembryonale Membran dem Nährstoff -und Sauerstofftransport des Hühnerembryos (Ribatti, 2010b). Auf der CAM angewachsene Tumoren können entnommen werden und weiteren Untersuchungen wie Fixation und Färbungen zugeführt werden. Im Hühnerei kommen vier extraembryonale Membranen vor, die den Hühnerembryo umgeben: Allantois (embryonale Harnblase), Chorion (Zottenhaut), Amnion und Dottersack (Ribatti, 2010b) (siehe Abb. 1-2). Das Heranreifen des Hühnerembryos umfasst 21 Tage bis zum Schlüpfen (Ribatti, 2010b). An Tag 5 bis 6 der Embryonalentwicklung wird die CAM durch Fusion von Chorion und Allantois gebildet (Romanoff, 1960). Um den Tag 8 haben die ersten Gefäße ein arteriovenöses System gebildet und bis Tag 18 das Gefäßsystem endgültig ausgebildet (Ausprunk et al, 1974).

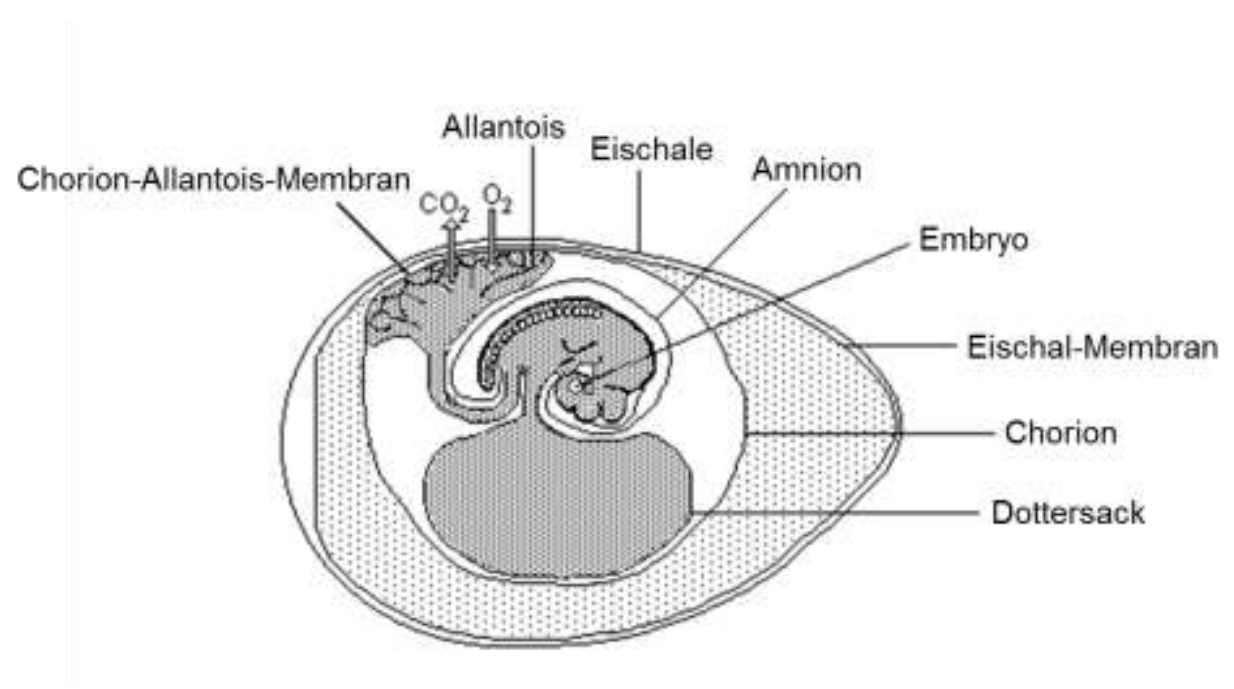

Abb. 1-2: Ein Embryo in einem Hühnerei (Schema). (modifiziert nach: The Amniote Egg, 2007). 
Die CAM dient in erster Linie der Sauerstoff -und Nährstoffversorgung des Hühnerembryos, aber auch dazu im Gewebe produziertes $\mathrm{CO}_{2}$ wieder abzugeben (Deryugina \& Quigley, 2008b). Sie ist sehr dünn mit bis zu $100 \mu \mathrm{m}$ Dicke und bildet durch die dichte Lage zu den Poren der Eierschale und einem eigenen dichten Gefäßnetzwerk ein effektives Versorgungssystem (Deryugina \& Quigley, 2008b). Weitere Aufgaben der CAM bestehen in dem Transport von Elektrolyten, der Lagerung von Exkrementen und der Mobilisation von Calcium der Eierschale zur Knochenmineralisierung des Hühnerembryos (Ribatti, 2010b). Der CAM-Assay stellt ein gutes Modell dar, mit dem sich Entwicklung, Verhalten und Ausbreitung von Krebszellen erforschen lässt (Fortune et al, 2000). Besonders die Erforschung der für Tumoren essentiellen Neoangiogenese brachte in letzter Zeit neue Erkenntnisse (Wilting et al, 1996; Deryugina \& Quigley, 2008b, Ribatti, 2010a). Die hohe Blut - und Lymphgefäßdichte der CAM ermöglicht in vivo die Erforschung von Tumoren (Romanoff, 1960; Wilting et al, 1996). Das adaptive Immunsystem des Hühnchens kann nicht in die Entwicklung des heranwachsenden Tumors eingreifen, da es erst 3 Wochen nach dem Schlüpfen des Hühnchens voll entwickelt ist (Weber \& Mausner, 1977). Somit stellt das Modell CAM-Assay insgesamt eine gut reproduzierbare, preiswerte und nicht allzu zeitintensive Methode zur Erforschung von Tumorwachstum in vivo dar.

\section{$1.5 \quad$ Ausgangslage}

Vorarbeiten der Arbeitsgruppe haben gezeigt, dass LEF1 aberrant in Tumoren von BurkittLymphomzelllinien exprimiert wird und dass Zelllinien ein geeignetes Modell darstellen, um die Rolle von LEF1 im BL zu zeigen (Walther et al, 2013). Mithilfe von transientem LEF-1 Knockdown (KD) konnten in vitro Zielgene des Transkriptionsfaktors beschrieben werden (Walther et al, 2013). Des Weiteren wurde in Kooperation mit der Arbeitsgruppe von Prof. Dr. Jörg Wilting aus der Anatomie Göttingen gezeigt, dass BL-Zellen auf der CAM wachsen und das Xenograft-Modell CAM-Assay für die Analyse von LEF1-assoziierten Funktionen genutzt werden kann (Becker et al, 2012). Die exakte biologische Funktion von LEF1 im BurkittLymphom bleibt jedoch unklar. Zur Erforschung von LEF1 wurden zu diesem Zwecke Zelllinien etabliert in denen die Expression von LEF1 durch Knockdown reduziert war. Die stabile Transduktion an sich stellte schon einen Fortschritt dar, da es hierbei nicht wie in Vorarbeiten zu einer Modifikation der Lymphomzellen kam. Somit standen für die Versuche LEF1-aberrante, sowie LEF1-defiziente BL-Zelllinien zur Verfügung, die jedoch noch nicht ausreichend charakterisiert waren. 


\subsection{Aufgabenstellung}

Das Ziel dieser Arbeit war es, die Eignung des Xenograft-Modells CAM-Assay für die Erforschung biologischer Funktionen von aberrant exprimiertem LEF1 in Burkitt-Lymphomen weiter zu untersuchen. Außerdem sollte gezeigt werden, wie sich eine reduzierte Expression von LEF1 in Burkitt-Lymphomen auf das Lymphom im Xenograft-Modell auswirkt. 


\section{$2.1 \quad$ Material}

\subsubsection{Geräte}

\begin{tabular}{|c|c|}
\hline Gerät & Hersteller \\
\hline Accu Jet & Brand, Hamburg, Deutschland \\
\hline Brutschrank Cytoperm & Heraeus Instruments, Hanau, Deutschland \\
\hline Centrifuge $5415 \mathrm{D}$ & Eppendorf AG, Hamburg, Deutschland \\
\hline Centromat MO Schüttler & B. Braun AG, Melsungen, Deutschland \\
\hline $\begin{array}{l}\text { Elektrophorese-Kammer und Wet-Blot- } \\
\text { System }\end{array}$ & Bio-Rad GmbH, München, Deutschland \\
\hline FACScan Durchflusszytometer & Becton Dickinson, Heidelberg, Deutschland \\
\hline $\begin{array}{lll}\text { GFL } 3005 & \text { Schüttelapparat } & \text { mit } \\
\text { Kreisbewegung } & & \end{array}$ & GFL, Burgwendel, Deutschland \\
\hline Glimmer-Sägeblatt 0,4 mm & Seipp, Langgöns, Deutschland \\
\hline Hera freeze $-80^{\circ} \mathrm{C}$ freezer & Heraeus Instruments, Hanau, Deutschland \\
\hline Ikamag RCT Magnetrührer/Heizplatte & IKA, Staufen, Deutschland \\
\hline Inverses Durchlichtmikroskop Televal 31 & Carl Zeiss AG, Jena, Deutschland \\
\hline Inotech Cell Harvester & Wallac Distribution, Freiburg, Deutschland \\
\hline Leica DM5000 B & Leica Microsystems, Wetzlar, Deutschland \\
\hline Leica DFC290 & Leica Microsystems, Wetzlar, Deutschland \\
\hline Leica M 125 & Leica Microsystems, Wetzlar, Deutschland \\
\hline Leica MZ16 FA & Leica Microsystems, Wetzlar, Deutschland \\
\hline Luminescent Image Analyzer LAS-4000 & Fujifilm, Düsseldorf, Deutschland \\
\hline Microm HM 355S & MICROM, Walldorf, Deutschland \\
\hline Multifuge 3 L-R & Heraeus Instruments, Hanau, Deutschland \\
\hline Neubauerzählkammer & $\begin{array}{l}\text { LO Laboroptik GmbH, Friedrichsdorf, } \\
\text { Deutschland }\end{array}$ \\
\hline Pinzette Dumont 5-Inox-E & Sigma, Osterode, Deutschland \\
\hline Pipetboy & Integra Biosciences, Fernwald, Deutschland \\
\hline $\begin{array}{lll}\text { Microflow } & \text { Laminar } & \text { Downflow } \\
\text { Workstation } & & \\
\end{array}$ & Bioquell, UK \\
\hline Varistain $^{\mathrm{TM}}$ 24-4 Automatic Slide Stainer & Thermo Fisher Scientific Inc., Waltham, USA \\
\hline SunriseTM Mikrotiterplatten-Lesegerät & Tecan, Crailsheim, Deutschland \\
\hline Shandon Citadel 2000 tissue processor & Thermo Fisher Scientific Inc., Waltham, USA \\
\hline Shandon Histocentre ${ }^{\mathrm{TM}} 3$ & Thermo Fisher Scientific Inc., Waltham, USA \\
\hline Taumelrollmischer RM 5 & Hecht-Assistent, Sondheim, Deutschland \\
\hline Thermocycler 60 Wasserbad & Bio-med GmbH, Theres, Deutschland \\
\hline Tischzentrifuge $1-15 \mathrm{k}$ & Sigma, Osterode, Deutschland \\
\hline Ultra Low $-152^{\circ} \mathrm{C}$ freezer & Sanyo, München, Deutschland \\
\hline
\end{tabular}




\begin{tabular}{|l|l|}
\hline Vortex Genie 2 & Schütt Labortechnik, Göttingen, Deutschland \\
\hline Waage L2200S & Sartorius, Göttingen, Deutschland \\
\hline Wasserbad & Köttermann Uetze/Hänigsen, Deutschland \\
\hline Zeiss Axis Kop 40 & Carl Zeiss AG, Jena, Deutschland \\
\hline $\begin{array}{l}\text { 1450 MicroBeta Trilux Liquid Scintilation } \\
\text { and Luminescence Counter }\end{array}$ & Wallac Distribution Freiburg \\
\hline
\end{tabular}

Tab. 2-1: verwendete Geräte

\subsubsection{Verbrauchsmaterial}

\begin{tabular}{|c|c|}
\hline Material & Hersteller \\
\hline 96-Well-Platte (Rund-/Flachboden) & Sarstedt, Nümbrecht, Deutschland \\
\hline Bijou Container $7 \mathrm{ml}$ & Thermo Fisher Scientific Inc., Waltham, USA \\
\hline Cellstar tissue culture dishes & Greiner Bio-One, Kremsmünster, Österreich \\
\hline Deckgläser & Menzel, Braunchschweig, Deutschland \\
\hline Einbettformen aus Metall & Carl Roth GmbH, Karlsruhe, Deutschland \\
\hline Einfrierröhrchen & Nunc, Wiesbaden, Deutschland \\
\hline Falcon Röhrchen (15 ml, $50 \mathrm{ml})$ & Sarstedt, Nümbrecht, Deutschland \\
\hline Filter Tips $(10 \mu \mathrm{l}, 100 \mu \mathrm{l}, 1000 \mu \mathrm{l})$ & Sarstedt, Nümbrecht, Deutschland \\
\hline Filtropur S 0,2 & Sarstedt, Nümbrecht, Deutschland \\
\hline Glass Fiber Filter 90 × $120 \mathrm{~mm}$ & Perkin Elmer®, Waltham, USA \\
\hline Leukosilk & BSN medical, Hamburg Deutschland \\
\hline Nitrozellulosemembran Hybond ${ }^{\mathrm{TM}}$-C Extra & $\begin{array}{lll}\text { Amersham } & \text { Biosciences, } & \text { Freiburg, } \\
\text { Deutschland } & & \\
\end{array}$ \\
\hline Objektträger Super Frost ${ }^{\circledR}$ & Carl Roth GmbH, Karlsruhe, Deutschland \\
\hline Pasteur-Plast Pipetten, steril & ratiolab®, Dreieich, Deutschland \\
\hline Polystyrene Round-Bottom Tube $5 \mathrm{ml}$ & BD Biosciences, New Jersey, USA \\
\hline Reaktionsgefäße $(0,5 \mathrm{ml}, 1,5 \mathrm{ml}, 2,0 \mathrm{ml})$ & Eppendorf, Hamburg, Deutschland \\
\hline Rotilabo®- Einbettkassetten & Carl Roth GmbH, Karlsruhe, Deutschland \\
\hline Serologische Pipetten $(5 \mathrm{ml}, 10 \mathrm{ml}, 25 \mathrm{ml})$ & Sarstedt, Nümbrecht, Deutschland \\
\hline Sample Bag für MicroBetaTM 90 x 120 mm & Perkin Elmer®, Waltham, USA \\
\hline Filterpapier (Diethylaminoethyl-Zellulose) & Whatman GmbH, Dassel, Deutschland \\
\hline $\begin{array}{l}\text { Zellkulturflaschen mit Belüftungskappe (25 } \\
\mathrm{cm} 2, \quad 75 \quad \mathrm{~cm} 2, \quad 175 \quad \mathrm{~cm} 2) \text { für } \\
\text { Suspensionszellen }\end{array}$ & Sarstedt, Nümbrecht, Deutschland \\
\hline
\end{tabular}

Tab. 2-2: verwendete Verbrauchsmaterialien 


\subsubsection{Chemikalien}

\begin{tabular}{|c|c|}
\hline Chemikalien & Hersteller \\
\hline 4-IPBA (4-Iodophenylboronic acid) & Sigma-Aldrich, München, Deutschland \\
\hline$\alpha$-Thiolglycerol & Sigma-Aldrich, München, Deutschland \\
\hline Acrylamid/Bisacrylamid $40 \%$ & BioRad, München, Deutschland \\
\hline Ammoniumpersulfat (APS) (10 \% in $\mathrm{H} 2 \mathrm{O})$ & Sigma-Aldrich, München, Deutschland \\
\hline Auto MACS ${ }^{\mathrm{TM}}$ Running Buffer & Miltenyi Biotec, Gladbach, Deutschland \\
\hline Betaplate Scint Szintillationscocktail & Perkin Elmer®, Waltham, USA \\
\hline $\begin{array}{l}\text { BD } \text { Matrigel }^{\mathrm{TM}} \text { Basement } \\
\text { Matrix }\end{array}$ & BD Biosciences, New Jersey, USA \\
\hline Bovine serum albumin (BSA) & Serva, Heidelberg, Deutschland \\
\hline Bromphenolblau & Sigma-Aldrich, München, Deutschland \\
\hline Calcium-Chlorid $\left(\mathrm{CaCl}_{2}\right)$ & Merck KGaA, Darmstadt, Deutschland \\
\hline $\begin{array}{l}\text { Complete }^{\mathrm{TM}} \text { Proteinaseninhibitor Cocktail } \\
\text { Tablets }\end{array}$ & Roche, Basel, Schweiz \\
\hline Dimethyl sulfoxide (DMSO) & Sigma-Aldrich, Taufkirchen, Deutschland \\
\hline DPX Eindeckmedium für Histologie & Sigma-Aldrich, München, Deutschland \\
\hline Essigsäure $100 \%$ & Merck KGaA, Darmstadt, Deutschland \\
\hline Eosin B & Carl Roth GmbH, Karlsruhe, Deutschland \\
\hline Ethanol 99\% & J.T. Baker, Griesheim, Deutschland \\
\hline Fetal Calf Serum (FCS) & Sigma-Aldrich, Taufkirchen, Deutschland \\
\hline Formaldehyd & Sigma-Aldrich, Taufkirchen, Deutschland \\
\hline Formaldehyd-Lösung 37\% & Merck KGaA, Darmstadt, Deutschland \\
\hline $\begin{array}{l}\text { Full Range Rainbow Molecular Weight } \\
\text { Markers RPN800E }\end{array}$ & GE Healthcare, München, Deutschland \\
\hline Giemsa Stammlösung & Carl Roth GmbH, Karlsruhe, Deutschland \\
\hline Glycin & Carl Roth GmbH, Karlsruhe, Deutschland \\
\hline Hämatoxylin & Carl Roth GmbH, Karlsruhe, Deutschland \\
\hline Isopropanol & Sigma-Aldrich, Taufkirchen, Deutschland \\
\hline Kalium-Chlorid $(\mathrm{KCl})$ & Merck KGaA, Darmstadt, Deutschland \\
\hline Luminol & Sigma-Aldrich, Taufkirchen, Deutschland \\
\hline Mayer's haemalaun solution & Merck KGaA, Darmstadt, Deutschland \\
\hline Methanol 99\% & J.T. Baker, Deventer, Niederlande \\
\hline Methyl-3H-Thymidin & $\begin{array}{l}\text { Hartmann Analytic } \mathrm{GmbH} \text {, Braunschweig, } \\
\text { Deutschland }\end{array}$ \\
\hline Milchpulver & Carl Roth GmbH, Karlsruhe, Deutschland \\
\hline Natrium-Chlorid $(\mathrm{NaCl})$ & Merck KGaA, Darmstadt, Deutschland \\
\hline Natrium dodecy sulfat (SDS) & Merck KGaA, Darmstadt, Deutschland \\
\hline Natrium-Desoxycholat & Merck KGaA, Darmstadt, Deutschland \\
\hline NP-40 Igepal (Nonidet P-40) & Sigma-Aldrich, Taufkirchen, Deutschland \\
\hline Paraplast Plus ${ }^{\circledR}$ & Sigma-Aldrich, Taufkirchen, Deutschland \\
\hline
\end{tabular}




\begin{tabular}{|l|l|}
\hline Penicillin/Streptomycin (P/S) & Sigma-Aldrich, Taufkirchen, Deutschland \\
\hline Phos-Stop & Roche, Basel, Schweiz \\
\hline Phophat gepufferte Salzlösung (PBS) & Pan Biotech, Aidenbach, Deutschland \\
\hline Pikrinsäure & Merck KGaA, Darmstadt, Deutschland \\
\hline Puromycin & Invivo Gen, San Diego, USA \\
\hline PMSF & Sigma-Aldrich, Taufkirchen, Deutschland \\
\hline $\begin{array}{l}\text { Ponceau S- Lösung (0,1\% Ponceau S in 5\% } \\
\text { Essigsäure) }\end{array}$ & Sigma-Aldrich, Taufkirchen, Deutschland \\
\hline ReBlot plus mild & Millipore, Schwalbach/Ts. Deutschland \\
\hline Roti®-Load (4x Probenpuffer) & Carl Roth GmbH, Karlsruhe, Deutschland \\
\hline Roti®-Quant & Carl Roth GmbH, Karlsruhe, Deutschland \\
\hline Roti®-Histokit II & Carl Roth GmbH, Karlsruhe, Deutschland \\
\hline RPMI-1640 mit L-Glutamin & Lonza Group Ltd., Basel, Schweiz \\
\hline Tetramethylethylenediamine (TEMED) & Sigma-Aldrich, Taufkirchen, Deutschland \\
\hline Thymidin-5'-3H & Sigma, Deisenhofen, Deutschland \\
\hline Trisbase Salzlösung (TBS) & Sigma-Aldrich, Taufkirchen, Deutschland \\
\hline Trypanblau 0.4 \% in PBS & $\begin{array}{l}\text { GIBCO BRL, Life Technologies, Eggenstein } \\
\text { Deutschland }\end{array}$ \\
\hline Tween-20 (T) & Merck KGaA, Darmstadt, Deutschland \\
\hline Wasser HPLC Grad & Merck KGaA, Darmstadt, Deutschland \\
\hline Xylol & Sigma-Aldrich, Taufkirchen, Deutschland \\
\hline
\end{tabular}

Tab. 2-3: verwendete Chemikalien

\subsubsection{Puffer, Lösungen und Medien}

\begin{tabular}{|l|l|}
\hline \multicolumn{1}{|c|}{ Puffer / Lösung / Ansatz } & \multicolumn{1}{c|}{ Zutaten } \\
\hline 4x SDS Probenpuffer & $500 \mu$ l Roti ${ }^{R} L o a d ~ 1 ~(4 x)$ \\
\hline 4\% Paraformaldhyd & $4 \%$ PFA in PBS \\
\hline Blockierlösung I & $5 \%$ BSA in TBS-T 0,1\% \\
\hline Blockierlösung II & $5 \%$ Milchpulver in TBS-T 0,1\% \\
\hline Bouin-Fixanz (wässriges Bouin) & 45 ml Formaldehyd 37\% \\
& 15 ml Pikrinsäure \\
& 3 ml Essigsäure 100\% \\
\hline Einfriermedium & $90 \%(\mathrm{v} / \mathrm{v})$ FCS \\
& $10 \%(\mathrm{v} / \mathrm{v})$ DMSO \\
\hline
\end{tabular}




\begin{tabular}{|c|c|}
\hline Lockelösung & $\begin{array}{l}152.45 \mathrm{mM} \mathrm{NaCl} \\
5.64 \mathrm{mM} \mathrm{KCl} \\
2.14 \mathrm{mM} \mathrm{CaCl}_{2}\end{array}$ \\
\hline Luminol-Lösung & $\begin{array}{l}100 \mathrm{mM} \text { Tris/HCl } \mathrm{pH} 8,8 \\
2,5 \mathrm{mM} \text { Luminol } \\
4 \mathrm{mM} 4-\mathrm{IPBA}\end{array}$ \\
\hline MACS-Cell-Separation-Puffer & $\begin{array}{l}1 \mathrm{x} \text { PBS } \\
0.5 \%(w / v) B S A\end{array}$ \\
\hline Mayers Hämalaun-Lösung & $\begin{array}{l}1 \mathrm{~g} \text { Hämalaun } \\
1000 \mathrm{ml} \text { Aqua bidest. } \\
0,2 \mathrm{~g} \mathrm{NaJO}_{3} \\
50 \mathrm{~g} \text { Kalialaun } \\
50 \mathrm{~g} \text { Chloraldydrat } \\
1 \mathrm{~g} \text { Zitronensäure }\end{array}$ \\
\hline $\begin{array}{l}\text { RIPA (Radio-Immunoprecipitation Assay)- } \\
\text { Lysepuffer }\end{array}$ & $\begin{array}{l}150 \mathrm{mM} \mathrm{NaCl} \\
50 \mathrm{mM} \text { TrisHCl }(\mathrm{pH} 7,4) \\
1 \%(\mathrm{v} / \mathrm{v}) \mathrm{NP}-40 \text { (Igepal) } \\
0,25 \%(\mathrm{w} / \mathrm{v}) \text { Natriumdeoxycholat } \\
0,1 \%(\mathrm{w} / \mathrm{v}) \mathrm{SDS} \\
\text { PMSF } 10 \quad \mathrm{mg} / \mathrm{ml} \quad(10 \quad \mu \mathrm{l} / \mathrm{ml} \quad \mathrm{RIPA}- \\
\text { Stocklösung; frisch zugeben) } \\
\text { Complete-Proteasehemmer 20x (40 } \mu \mathrm{l} / \mathrm{ml} \text {; } \\
\text { frisch zugeben) } \\
\text { Phos-Stop 20x (40 } \mu \mathrm{l} / \mathrm{ml} \text {; frisch zugeben) }\end{array}$ \\
\hline Sammelgellösung (5\% Gel) & $\begin{array}{l}15 \%(\mathrm{v} / \mathrm{v}) \text { Acrylamid/Bis Solution }(40 \%) \\
125 \mathrm{mM} \text { Tris Base } \mathrm{pH} 6.8 \\
0.1 \%(\mathrm{w} / \mathrm{v}) \mathrm{SDS} \\
5 \mathrm{mM} \text { EDTA }\end{array}$ \\
\hline
\end{tabular}




\begin{tabular}{|c|c|}
\hline SDS-PAGE-Laufpuffer (10x) & $\begin{array}{l}25 \mathrm{mM} \text { Trisbase } \\
1,92 \mathrm{M} \text { Glycin } \\
1 \%(\mathrm{w} / \mathrm{v}) \mathrm{SDS}\end{array}$ \\
\hline $\begin{array}{l}\text { SPF (specific pathogen free), befruchtete, } \\
\text { weiße Leghorn-Eier }\end{array}$ & $\begin{array}{l}\text { VALO BioMedia, Osterholz-Scharmbeck, } \\
\text { Deutschland }\end{array}$ \\
\hline Sammelgel (für ein Gel) & $\begin{array}{l}\text { 2,5 ml Sammelgel-Mix } \\
20 \mu \mathrm{l} \text { APS }(10 \%) \\
7,5 \mu 1 \text { TEMED }\end{array}$ \\
\hline TBS (1x) & $\begin{array}{l}20 \mathrm{mM} \text { Tris-Base } \mathrm{pH} 7,6 \\
137 \mathrm{mM} \mathrm{NaCl} \mathrm{pH} \mathrm{7,6}\end{array}$ \\
\hline TBS-T & $\begin{array}{l}\text { 1xTBS pH 7,6 } \\
0,1 \%(\mathrm{v} / \mathrm{v}) \text { Tween-20 }\end{array}$ \\
\hline Transferpuffer $(10 \mathrm{x})$ & $\begin{array}{l}25 \mathrm{mM} \text { Trisbase } \mathrm{pH} 8,3 \\
192 \mathrm{mM} \text { Glycin } \\
15 \%(\mathrm{v} / \mathrm{v}) \text { Methanol }\end{array}$ \\
\hline Trenngel-Mix (10\% Gel) & $\begin{array}{l}31.3 \%(\mathrm{v} / \mathrm{v}) \text { Acrylamid/Bis Solution (40 \%) } \\
332 \mathrm{mM} \text { Tris Base, } \mathrm{pH} 8.9 \\
3.33 \mathrm{mM} \text { EDTA }\end{array}$ \\
\hline $10 \%$ Trenngel (für $1 \mathrm{Gel}$ ) & $\begin{array}{l}5 \mathrm{ml} \text { Trenngel-Mix } \\
40 \mu \mathrm{l} \text { APS }(10 \%) \\
15 \mu 1 \text { TEMED }\end{array}$ \\
\hline Trypanblau-Lösung & $\begin{array}{l}\text { PBS } \\
0,4 \%(w / v) \text { Trypanblau }\end{array}$ \\
\hline Zellkultur Medium (für BL-2 Wildtyp) & $\begin{array}{l}\text { RPMI-1640 mit 4mM L-Glutamin } \\
10 \% \text { FCS } \\
1 \% \mathrm{P} / \mathrm{S}\end{array}$ \\
\hline Zellkultur Medium & $\begin{array}{l}\text { RPMI-1640 mit 4mM L-Glutamin } \\
10 \% \mathrm{FCS} \\
1 \% \mathrm{P} / \mathrm{S} \\
1 \mu \mathrm{g} / \mathrm{ml} \text { Puromycin }\end{array}$ \\
\hline
\end{tabular}

Tab. 2-4: verwendete Puffer, Lösungen und Ansätze 


\subsubsection{Antikörper}

\begin{tabular}{|l|l|l|}
\hline \multicolumn{1}{|c|}{ Antikörper } & \multicolumn{1}{|c|}{ Hersteller } & \multicolumn{1}{|c|}{\begin{tabular}{c}
\multicolumn{1}{c|}{ Verdünnung für } \\
Immunoblot
\end{tabular}} \\
\hline $\begin{array}{l}\text { Goat anti-mouse IgG-HRP } \\
\text { (D1609) }\end{array}$ & $\begin{array}{l}\text { Santa Cruz, Heidelberg, } \\
\text { Deutschland }\end{array}$ & $\begin{array}{l}1: 20000 \text { in 5\% } \\
\text { Milchpulver in T-BST } \\
0,1 \%\end{array}$ \\
\hline $\begin{array}{l}\text { Goat anti-rabbit IgG-HRP } \\
\text { (E1710) }\end{array}$ & $\begin{array}{l}\text { Santa Cruz, Heidelberg, } \\
\text { Deutschland } \\
1: 2000 \text { in 5\% BSA in T- } \\
\text { BST 0,1\% }\end{array}$ \\
\hline Mouse anti-GAPDH (6C5) & Abcam, Cambridge, UK & $\begin{array}{l}1: 20000 \text { in 5\% } \\
\text { Milchpulver in T-BST } \\
0,1 \%\end{array}$ \\
\hline Rabbit anti-LEF1 (C18A7) & $\begin{array}{l}\text { CellSignaling, Cambridge, } \\
\text { UK }\end{array}$ & $\begin{array}{l}\text { BST 0,1\% } \\
\text { US B }\end{array}$ \\
\hline
\end{tabular}

Tab. 2-5: verwendete Antikörper

\subsubsection{Zelllinien}

\begin{tabular}{|c|c|c|c|}
\hline Zelllinie & & Ursprung & Referenz \\
\hline BL-2 & $\begin{array}{l}\text { B-Zelle } \\
\text { EBV }\end{array}$ & $\begin{array}{l}\text { Burkitt-Lymphom, } \\
\text { negativ, DSMZ }\end{array}$ & Bertrand et al, 1981 \\
\hline
\end{tabular}

Tab. 2-6: verwendete Zelllinien

\subsubsection{Software}

\begin{tabular}{|l|l|}
\hline \multicolumn{1}{|c|}{ Software } & \multicolumn{1}{c|}{ Hersteller } \\
\hline Graph Pad Prism 5.04 for Windows & Graph Pad Software Inc., San Diego, USA \\
\hline IC Capture 2.0 & The Imaging Source, Bremen, Deutschland \\
\hline $\begin{array}{l}\text { Image J 1.48s (image processing and analysis } \\
\text { in Java) }\end{array}$ & $\begin{array}{l}\text { Rayne Rasband, National Institutes of } \\
\text { Health, Bethesda, USA }\end{array}$ \\
\hline LAS v 3.8 Leica Application Suite & Leica Microsystems, Wetzlar, Deutschland \\
\hline $\begin{array}{l}\text { Microsoft Word, Power Point, Excel (Office } \\
\text { 2010) }\end{array}$ & Microsoft, Redmont, USA \\
\hline NIS Elements F 2.20 & Nikon, Tokio, Japan \\
\hline
\end{tabular}

Tab. 2-7: verwendete Software 


\subsection{Methoden}

\subsubsection{Zellkultur}

\subsubsection{Zelllinien}

Die in dieser Arbeit verwendete Zelllinie BL-2 wurde 1979 einem 7-jährigen kaukasischen Patienten mit Burkitt-Lymphom (Stadium 3) aus dem Rückenmark entnommen und darauffolgend immortalisiert (Bertrand et al, 1981). Es handelt sich um in Suspension wachsende lymphatische Zellen. Das verwendete Zellkulturmedium war RPMI-1640 mit LGlutamin (10\% FCS, 1\% Penicillin/Streptomycin). Die lentiviral transduzierten Zelllinien benötigten für ihr Medium zusätzlich Puromycin in einer Konzentration von $1 \mu \mathrm{g} / \mathrm{ml}$.

\subsubsection{LEF1-Knockdown-Zelllinien}

Die Erforschung des Transkriptionsfaktors LEF-1 geschah mithilfe genetisch modifizierter BL2-Zelllinien. Durch Vorarbeiten von Dr. rer. nat. Sonja Eberth wurde der DNA der Modelllinie BL-2 mittels Viren ein pGIPZ-Konstrukt integriert, das LEF-1 in seiner Konzentration herunterreguliert (Knockdown). Diese Zellen wurden zur Verfügung gestellt, waren allerdings noch nicht hinreichend charakterisiert. Bei dem pGIPZ-Konstrukt handelt es sich um ein DNA-Fragment, das für den Selektionsmarker GFP (green fluorescent protein), für eine Puromycinresistenz und für eine small hairpin RNA (shRNA) codiert. Dieses DNAFragment wurde stabil in das Genom der Lymphomzellen mittels lentiviralem Gentransfer integriert. Nach diesem Schema wurden vier Zelllinien aus der parentalen BL-2 Zelllinie etabliert. Jedoch fand nur bei zwei dieser Zelllinien ein wirklicher Knockdown statt (BL-2 pGIPZ LEF-1 sh\#A \& sh\#E). Diese beiden Zelllinien werden im Folgenden auch als LEF1defizient bezeichnet. Bei den zwei anderen Zelllinien (BL-2 pGIPZ-Kontrollen, ctrl 1 und ctrl 2) handelt es sich um scrambled-Kontrollen deren shRNA keine Sequenzen im humanen Genom binden kann und es somit auch zu keiner Degradation von LEF-1 kommt (scrbZelllinien). Zudem gibt es noch einen Unterschied zwischen den beiden Knockdown-Zelllinien BL-2 pGIPZ LEF1 sh\#A und sh\#E, der in der genauen Bindestelle der shRNA mit der mRNA von LEF-1 liegt (siehe Tab. 2-1). Bei den zwei Kontroll-Zelllinien handelte es sich um zwei unabhängig voneinander etablierte Ansätze. Die genetisch manipulierten Zellen sind nicht in der Lage selber Viruspartikel zu bilden. 


\begin{tabular}{|l|l|}
\hline \multicolumn{1}{|l|}{ Zelllinie } & ShRNA-Bindungsstelle an der LEF 1- \\
\hline BL-2 Wildtyp & $\underline{\text { mRNA }}$ \\
\hline BL-2 pGIPZ LEF1 sh\#A & ---- \\
\hline BL-2 pGIPZ LEF1 sh\#E & 3' UTR (untranslatierte Region am 3` Ende) \\
\hline BL-2 pGIPZ ns-control (ctrl 1) & Exon 4 \\
\hline BL-2 pGIPZ ns-control (ctrl 2) & ----- \\
\hline
\end{tabular}

\subsubsection{Auftauen von Zelllinien}

Die Burkitt-Lymphom-Zelllinien wurden in Einfriermedium (10\% DMSO und 90\% FCS) in Kryoröhrchen bei $-150^{\circ} \mathrm{C}$ aufbewahrt. Für die Kultivierung wurden die Kryoröhrchen im Wasserbad bei $37^{\circ} \mathrm{C}$ aufgetaut und anschließend unter einer sterilen Werkbank mit $9 \mathrm{ml}$ vorgewärmten Medium vermischt. Anschließend wurde ein Aliquot für die Zellzahl -und Viabilitätsbestimmung abgenommen und der Rest für $7 \mathrm{~min}$ bei $21^{\circ} \mathrm{C}$ und $120 \mathrm{~g}$ zentrifugiert. Das Zellpellet wurde in frischem Nährmedium resuspendiert, sodass eine Konzentration von $5,0 \times 10^{6}$ Zellen/ml vorlag. Die Zellen wurden bei einer Dichte von 0,3 bis 1,0 x $10^{6} \mathrm{Zellen} / \mathrm{ml}$ in Zellkulturflaschen gehalten und im Brutschrank bei $37^{\circ} \mathrm{C}, 5 \% \mathrm{CO}_{2}$ und $95 \%$ Luftfeuchtigkeit unter sterilen Bedingungen inkubiert.

\subsubsection{Zellzahl -und Viabilitätsbestimmung}

Die Bestimmung der Zellzahl erfolgte mithilfe einer Neubauer-Zählkammer. Dazu wurde ein $10 \mu$ l-Aliquot der Zellsuspension mit $10 \mu \mathrm{l}$ Trypanblau-Lösung gemischt (1:1) und in die Zählkammer pipettiert. Trypanblau färbt nur die toten Zellen blau, da es für die intakte Zellmembran undurchlässig ist. Danach wurden unter dem Durchlichtmikroskop 4 definierte 
Bereiche der Zählkammer ausgezählt. Die Zellkonzentration wurde mit folgender Formel berechnet: Konzentration der Zellen/ml = Zellzahl: $4 \times 2 \times 10^{4}$

Mithilfe des bekannten Kulturvolumens konnte nun durch Multiplikation die Gesamtzellzahl errechnet werden. Die Viabilität der kultivierten Zellen wurde folgendermaßen bestimmt:

Viabilität [\%] $=($ Anzahl lebendiger Zellen $/$ Anzahl aller gezählten Zellen $) \times 100$

Die für die Versuche verwendeten Zellen hatten eine Viabilität von mindestens $90 \%$.

\subsubsection{Konservierung in Kryoröhrchen}

Für die Konservierung der Zelllinien in den Kryoröhrchen wurden etwa 5 x $10^{6}$ Zellen in $1 \mathrm{ml}$ Einfriermedium (10\% DMSO und 90\% FCS) resuspendiert. Anschließend wurden die Kryoröhrchen in einem Kryo-Container (Nalgene) über Nacht bei $-80^{\circ} \mathrm{C}$ belassen. Der KryoContainer ist mit $100 \%$ igem 2-Propanol gefüllt und bewirkt, dass die Zellen um $1^{\circ} \mathrm{C}$ pro Minute langsam abkühlen können. Am folgenden Tag wurden die Kryo-Röhrchen zur Langzeitaufbewahrung in die $-150^{\circ} \mathrm{C}$-Truhe umgelagert.

\subsection{2 ${ }^{3}$ H-Thymidin-Inkorporations-Assay}

Mittels ${ }^{3} \mathrm{H}$-Thymidin-Inkorporation wurde die Zellproliferation der in Kultur gehaltenen Zelllinien überprüft. Dafür wurden die Zellen in Triplikaten in eine 96-Well-Flachbodenplatte überführt. Pro Well wurden 3 x $10^{4}$ Zellen in $100 \mu$ Medium pipettiert. Nach $7 \mathrm{~h}$ Inkubation bei $37^{\circ} \mathrm{C}$ und $5 \% \mathrm{CO}_{2}$ wurde zu jedem Well 0,166 $\mu \mathrm{Ci}$ Methyl- ${ }^{3} \mathrm{H}-$ Thymidin gelöst in $10 \mu \mathrm{l}$ Medium dazugegeben. Nach weiteren $17 \mathrm{~h}$ Inkubation bei $37^{\circ} \mathrm{C}$ und $5 \% \mathrm{CO}_{2}$ wurden die Zellen dann mithilfe des Inotech Cell Harvesters auf ein Filterpapier transferriert und das luftgetrocknete Filterpapier mit $5 \mathrm{ml}$ Szintillationsflüssigkeit benetzt. Die Szintillation wurde anschließend mit dem 1450 MicroBeta Trilux Liquid Scintilation and Luminescence Counter (Wallac) gemessen.

\subsubsection{Durchflusszytometrie (FACS-Analyse)}

Mithilfe der Durchflusszytometrie können einzelne Zellen einer Zellpopulation auf Größe und Granularität, aber auch auf verschiedene Oberflächenmarker oder fluoreszierende Moleküle wie GFP untersucht werden. Zuvor müssen die Zellen in einem laminaren 
Trägerflüssigkeitsstrom fokussiert werden. Die Detektion der Zellen geschieht mithilfe eines Laserstrahls. Trifft der Laserstrahl auf eine Zelle wird er abgelenkt und bewirkt ein Streulicht. Detektoren messen die Beugung der Laserstrahlen. Die Detektion des Laserstrahls, der in Richtung des ursprünglichen Strahls gerichtet ist (Forward Scatter, FSC), bestimmt die Größe der Zellen, da die Ablenkung des Strahls vom Volumen der Zellen abhängt. Detektion von Laserstrahlen senkrecht des ursprünglichen Laserstrahls (Side Scatter, SSC) gibt Hinweise über die Granularität der Zellen, d.h. die Größe und Struktur der Zellkerne und Anzahl der Vesikel und Granula in den Zellen. Die Zellen können in einem Dot Plot aufgezeigt werden und verschiedene Zellen anhand ihrer Spezifitäten erkannt werden. Zudem können von anderen Kanälen weitere Charakteristika der Zellen erfasst werden. Beispielsweise Fluoreszenz (GFP in FL-3). Die Fluoreszenz kann dann wiederrum in einem Dot Plot gegen FSC, SSC oder eine weitere Fluoreszenz aufgetragen werden. Um festzulegen, ob ein bestimmter Event als positiv oder negativ gewertet wird, wird eine Schwelle (threshold) definiert. Letztendlich ergibt sich daraus der Anteil der Positiven und Negativen innerhalb einer Subpopulation. In dieser Arbeit ging es darum den Erfolg der lentiviralen Transduktion der BL2-Zellen zu überprüfen, indem der Anteil GFP-positiver Zellen detektiert wurde. Dazu wurde ein Aliquot der Zellsuspension in eine Rundboden-Röhrchen überführt und für $7 \mathrm{~min}$ bei $120 \mathrm{~g}$ und Raumtemperatur (RT) zentrifugiert. Anschließend wurden die Zellen in $500 \mu \mathrm{l}$ autoMACS-running buffer resupendiert. Vor jeder Messung wurde die Zellsuspension mit dem Vortexer durchmischt.

\subsubsection{Proteinbiochemische Methoden}

\subsubsection{Herstellung der Zelllysate}

Für die Herstellung der Zelllysate wurden jeweils $5 \mathrm{ml}$ der Zellsuspensionen für 7 min bei $120 \mathrm{~g}$ und $21^{\circ} \mathrm{C}$ zentrifugiert und anschließend in $1 \mathrm{ml}$ PBS gewaschen. Nach erneuter Zentrifugation für 5 min bei $400 \mathrm{~g}$ und Raumtemperatur wurde der Überstand mit einer Pipette abgesaugt. Um nun die Proteine aus den geernteten Zellpellets zu isolieren wurden diese in RIPA-Lysepuffer resuspendiert (50 $\mu$ l RIPA-Puffer pro 1 x $10^{6}$ Zellen). Der RIPA-Lysepuffer löst die Zellmembranen auf und bewirkt, dass die Proteine aus den Zellen freigesetzt werden. Anschließend wurden die Proben auf Eis für 30 Minuten inkubiert und die Suspension anschließend für $15 \mathrm{~min}$ bei $14500 \mathrm{~g}$ und $4{ }^{\circ} \mathrm{C}$ zentrifugiert. 


\subsubsection{Bestimmung der Proteinkonzentrationen}

Aus den Überständen konnte nun die enthaltene Proteinkonzentration ermittelt werden. Die Bestimmung erfolgte mittels der Methode nach Bradford (Bradford 1976). Das zugrunde liegende Prinzip ist Folgendes. Der Farbstoff Coomassie Brilliant Blue G-250 (im Roti®-Quant 5x) wird zu den Proteinlösungen gegeben. Dieser bindet in saurer Lösung an basische und aromatische Aminosäuren der Proteine und bewirkt dadurch eine Verschiebung des Absorptionsmaximums des Farbstoffs von $465 \mathrm{~nm}$ zu $595 \mathrm{~nm}$. Die Absorption bei $595 \mathrm{~nm}$ ist umso höher, je höher die Proteinkonzentration einer Lösung ist. Die Proteinlysate inklusive RIPA-Puffer wurden 1:40 mit Wasser verdünnt und $50 \mu 1$ der Verdünnungen in Triplikaten in eine 96-Mikrotiterplatte pipettiert. Anschließend wurde $200 \mu$ l Roti®-Quant (1x) zu den vorgelegten Proben gegeben. Danach wurde die jeweilige OD595 photometrisch gemessen. Anhand einer zuvor bestimmten BSA-Standardkurve (Bovine Serum Albumin) konnte die Proteinkonzentration ermittelt werden.

\subsubsection{SDS-Polyacrylamid-Gelelektrophorese (SDS-PAGE)}

Bei der in dieser Arbeit durchgeführten Gelelektrophorese handelte es sich um eine denaturierende diskontinuierliche Sodiumdodecylsulfat (SDS)- PAGE (Ahn et al, 2001; Laemmli, 1970). Die Lysate wurden mit Probenpuffer 4x im Verhältnis 1:4 gemischt und für 5 min bei $95^{\circ} \mathrm{C}$ im Thermocycler denaturiert. Es wurden zwischen 15 und $40 \mu \mathrm{g}$ Protein pro Geltasche berechnet und zusammen mit einem Protein-Molekulargewichtsstandard (RainbowMarker) aufgetragen. Das SDS bewirkt eine Proteindenaturierung und eine negative Gesamtladung der Proteine. Die Elektrophorese lief zunächst bei $20 \mathrm{~mA}$ im neutralen 5\% Sammelgel bis sich alle Geltaschenbeladungen auf einer Ebene angesammelt hatten (nach etwa 20 Minuten). Die Auftrennung der Proteine im sauren 10\% Trenngel erfolgte bei $40 \mathrm{~mA}$ bis die Bromphenolblau-Bande das Ende des Gels erreicht hatte.

\subsubsection{Western Blot}

Der Transfer der aufgetrennten Proteine vom Polyacrylamidgel auf die Nitrozellulosemembran erfolgte mithilfe eines zum Gel senkrecht stehenden elektrischen Feldes. In diesem Falle wurde ein sogenannter Nassblot im Transferpuffer für $1 \mathrm{~h}$ bei $4^{\circ} \mathrm{C}$ und konstanter Spannung von $100 \mathrm{~V}$ durchgeführt. Danach wurde die Membran mit dem roten Farbstoff Ponceau S gefärbt. Ponceau S färbt alle Proteine. So wird der Erfolg des Proteintransfers, als auch eventuelle 
Proteinschwankungen zwischen den einzelnen Geltaschen überprüft. Nach Aufnahme eines Bildes der Nitrozellulosemembran wurde das Ponceau S mit 0,05\% TBS-Tween (TBS-T) wieder von der Membran gewaschen.

\subsubsection{Immunoblotting}

Zur Sichtbarmachung bestimmter Proteine auf der Nitrozellulosemembran bedient man sich der Verwendung spezifischer Antikörper (immunchemischer Nachweis). Diese läuft in zwei Etappen. Nach Inkubation der Membran mit Blockierlösung (5\% Bovines Serumalbumin oder 5\% Milchpulver in TBS-T 0,05\%) für $1 \mathrm{~h}$ zur Absättigung unspezifischer Bindungsstellen und dreimaligem Waschen der Membran in TBS-T 0,05\% wurde diese über Nacht bei $4^{\circ} \mathrm{C}$ mit dem Primärantikörper Anti-LEF1 inkubiert. Danach wurde die Membran nach dem vorherigen Schema gewaschen und für $1 \mathrm{~h}$ bei Raumtemperatur mit dem Sekundärantikörper (goat antirabbit IgG-HRP) inkubiert. Dieser erkennt speziesspezifisch den Primärantikörper. An den Sekundärantikörper ist eine horse radish-Peroxidase (HRP) gekoppelt, die eine Lumineszenzreaktion katalysieren kann. Anschließend wurde die Membran dreimal für etwa 10 min in TBS-T 0,05\% gewaschen. Zur Sichtbarmachung der spezifisch gebundenen Proteine wurden Luminol- und Peroxid-Lösung im Verhältnis 1:1 für ungefähr 1 min auf die Membran gegeben. Diese Chemilumineszenz-Lösung dient als Substrat der Peroxidase, die das enthaltene Peroxid unter Oxidation von Luminol und Aussendung eines Photons umsetzt. Bei der anschließenden Belichtung und digitalen Aufnahme der Membran in einem Luminescent Image Analyser (Fujifilm) wurden die Proteinbanden sichtbar. Auf derselben Membran können nacheinander verschiedene Antikörper benutzt werden. Dafür müssen jedoch zuvor die vorherigen Antikörper von der Membran gelöst werden. Dies wird mit dem Waschen in ReBlot plus Mild Lösung (1:10 verdünnt in A. bidest) für 15 min bei Raumtemperatur erreicht. Nach dreimaligen Waschen in TBS-T 0,05\% und erneutem Blockieren in 5\%iger Lösung kann die Membran dann mit einem weiteren Primärantikörper, hier anti-GAPDH (AntiGlycerinaldehyd-3-phosphat-Dehydrogenase) inkubiert werden. GAPDH ist ein Protein, das in allen Zelllinien in gleicher Konzentration vorliegt und somit als Beladungskontrolle dienen kann. Die Membran wurde danach wieder gewaschen und mit einem entsprechenden Sekundärantikörper (goat anti-mouse IgG-HRP) inkubiert. Wie im oben beschriebenen Verfahren wurde GAPDH durch die oben genannte Chemolumineszenzreaktion detektiert. 


\subsubsection{CAM-Assay}

Der CAM Assay (CAM steht für Chorioallantois-Membran) ist ein Verfahren zur Analyse von Tumoren, deren Bildung, Anwachsen und Verbreitung in vivo im Hühnchenmodell. Dieser ermöglicht es Tumoren auf einer hühnereigenen Membran innerhalb des Eis wachsen zu lassen. Dafür werden die Tumorzellen direkt auf die CAM pipettiert. Der CAM-Assay folgt einem bestimmten Ablauf, der das Freilegen der CAM, das Beimpfen der Membran mit in vitro kultivierten Tumorzellen und die Extraktion des angewachsenen Tumors beinhaltet. Anschließend können die Tumoren zur näheren Untersuchung fixiert, eingebettet, geschnitten und gefärbt werden.

\subsubsection{Beginn des Bebrütens/Start der Embryonalentwicklung}

Die Hühnereier wurden zuvor bei Raumtemperatur getrocknet und in den Inkubator gelegt $\left(37,8^{\circ} \mathrm{C}, 80 \%\right.$ relative Luftfeuchtigkeit).

\subsubsection{Fensterung der Eier}

An Tag 3 der Embryonalentwicklung wurde ein etwa $0,5 \mathrm{~cm}^{2}$ großes Loch in die Eierschale gesägt. Nach dem Abheben der Eierschale wurde ein sehr kleines Loch in die Eihaut gepiekst. Dabei kam es dazu, dass der Embryo absank. Der nun freie Blick ins Innere des Eis zeigt mit Blutgefäßen durchzogene Membranen. Gewöhnlich ist sogar ein kleines schlagendes Herz zu erkennen. Jedenfalls ist dies der Beweis, dass das Ei befruchtet wurde. Zuletzt wurde das Fenster über dem Embryo mit Leukosilk verschlossen und das Ei in der Petrischale im Inkubator für weitere 7 Tage platziert. 

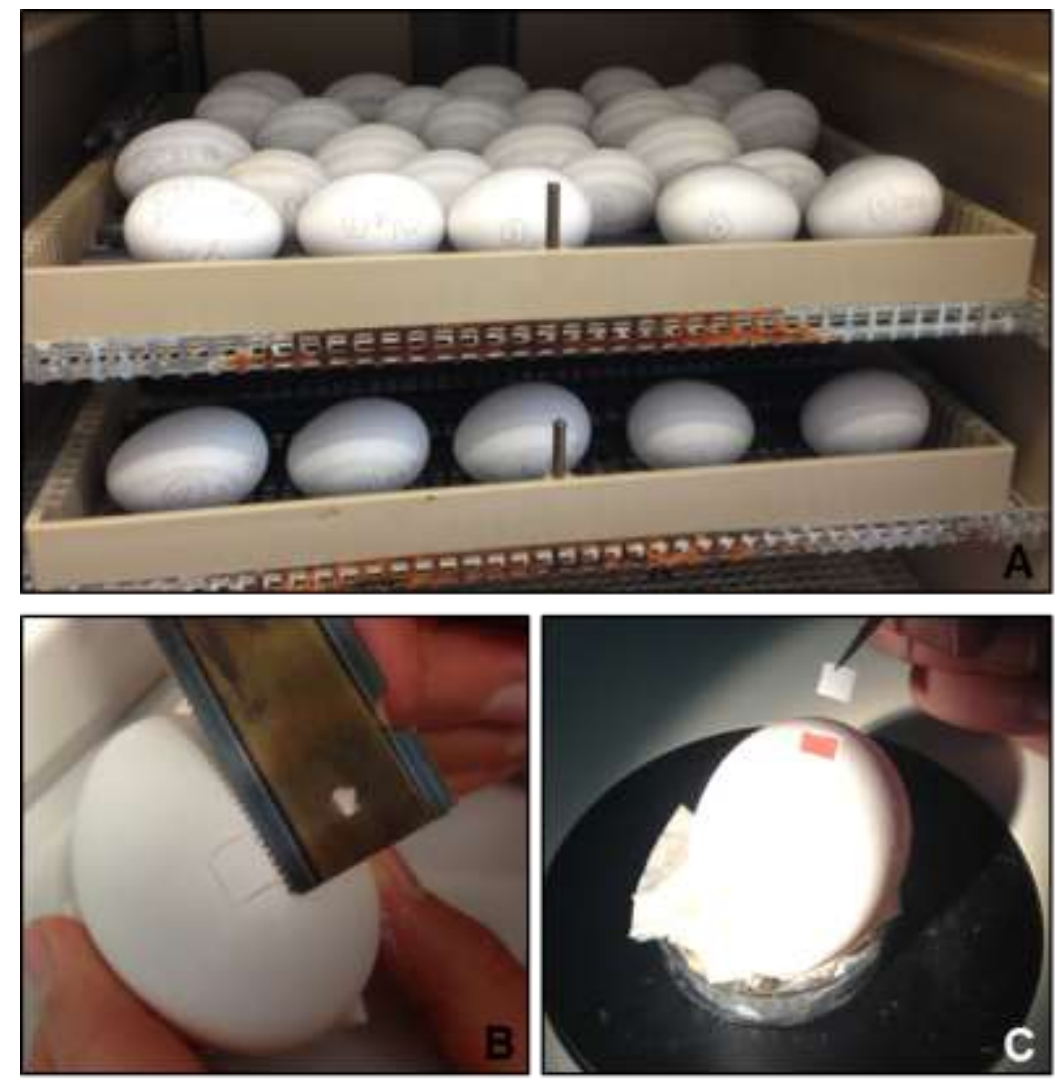

Abb. 2-1: Inkubation der Eier im Brutschrank (A) und Freilegen der CAM durch Sägen eines Fensters (B, C).

\subsubsection{Beimpfung der CAM mit den BL2-Zellen}

Die Zelllinien, die Tage zuvor in Kultur gebracht wurden, wurden am Morgen des Beimpfungstages in der Neubauer-Zählkammer gezählt. Dann wurde die entsprechende Menge an Zellen ( $\left.2 \times 10^{6} / \mathrm{Ei}\right)$ herunterzentrifugiert ( $7 \mathrm{~min}$ bei $120 \mathrm{~g}$ ) und jeweils so mit frischem

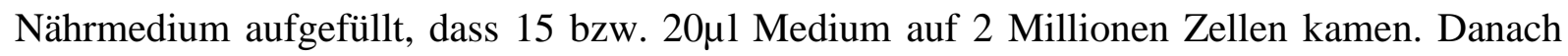
wurde die gleiche Menge an BD Matrigel ${ }^{\mathrm{TM}}$ dazu gemischt und die Tropfen $\left(2 \times 10^{6}\right.$ Zellen/Tropfen) in eine Petrischale gegeben. Nun wurden die Tropfen für eine halbe Stunde in den Inkubator bei $37,8^{\circ} \mathrm{C}$ gestellt. Dabei bekommen die zuvor flüssigen Tropfen einen visköseren Aggregatzustand. Ohne das MatriGel würden die Tropfen auf der CAM zerfließen und das Anwachsen von soliden Tumoren deutlich unwahrscheinlicher. Um die Zellen mit der sterilen Pipette auftragen zu können wurde vorher das Leukosilk-Band über dem Fenster mit einer desinfizierten Schere herausgeschnitten. Nach dem Auftragen der Lymphomzellen wurde das Loch wiederum mit Leukosilk-Band verschlossen und das Ei für weitere 4 Tage zurück in den Inkubator gelegt. 


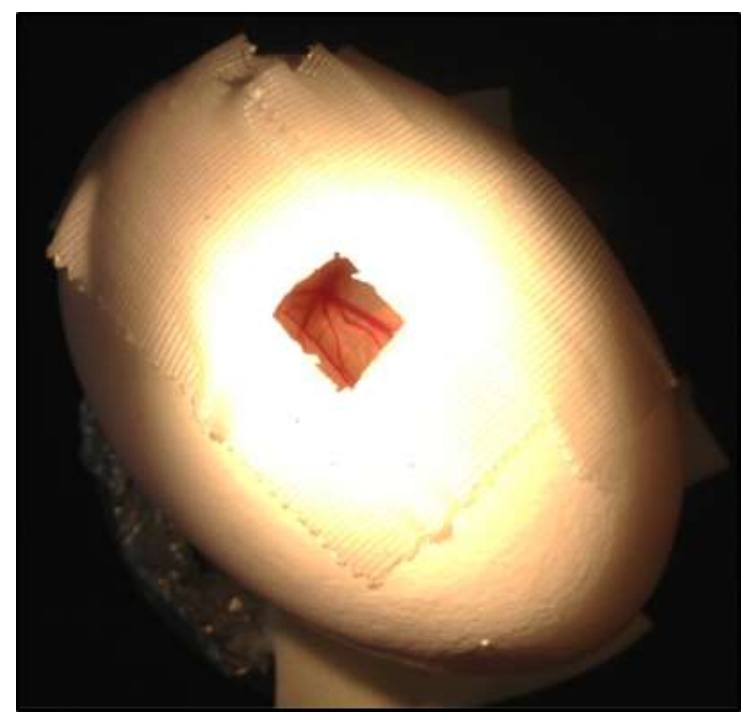

Abb. 2-2: Blick auf die CAM an Tag 11 der Embryonalentwicklung. Die CAM ist bereits stark vaskularisiert.

\subsubsection{Ernte der Tumoren}

An Tag 14 der Embryonalentwicklung wurden die Tumoren geerntet. Zunächst wurde das Leukosilk-Band über dem Fenster mit einer Schere herausgeschnitten. Im Anschluss wurde vorsichtig mit der Schere umliegende Eierschale kreisförmig entfernt, sodass ein guter Zugang zum Tumor bestand. Nun wurde der Tumor weiträumig mit umliegender CAM mit einer Wecker-Irisschere herausgeschnitten und mit dem Hebelöffel kurz in PBS zum Waschen überführt. Darauffolgend wurden von den Tumoren noch in den Petrischalen lichtmikroskopische sowie fluoreszenzmikroskopische Aufnahmen gemacht. Zum Schluss wurden die Tumoren in Schnappdeckelgläschen zur etwa einwöchigen Fixierung in wässrige Bouin-Lösung überführt und bei $4^{\circ} \mathrm{C}$ gelagert. 

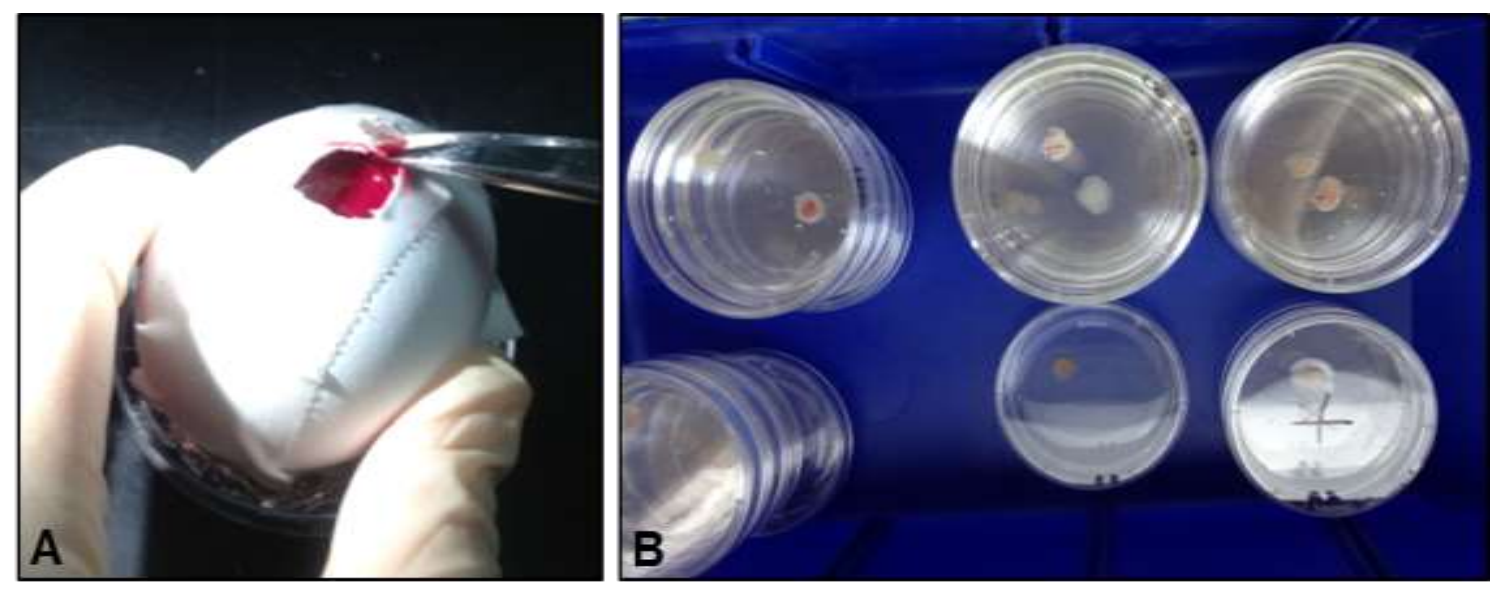

Abb. 2-3: Ernte der Tumoren (A) und Aufbewahrung in Petrischalen mit PBS (B).

\subsubsection{Ausmessung der Tumorflächen}

Mithlife der Software ImageJ wurden die Lichtbilder der Tumoren ausgemessen. Dazu wurde auf dem Computerbildschirm das jeweilige Bild aufgerufen und mit der Computermaus eine Linie um den Tumor eingezeichnet. Anhand einer vorher bestimmten $1 \mathrm{~cm}-M e s s s k a l a$ konnte so die Fläche bestimmt werden.

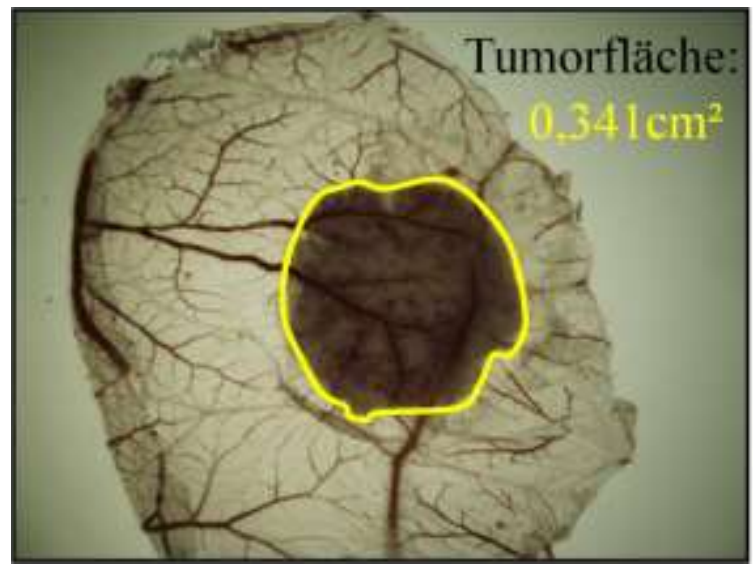

Abb. 2-4: Flächenbestimmung eines CAM-Tumors mithilfe von ImageJ. Das Lichtbild wurde auf dem Desktop aufgerufen. Mit der Computermaus wurde eine feine Linie um den Tumor eingezeichnet und anschließend die eingekreiste Fläche berechnet. 


\subsubsection{Paraffineinbettung der Tumoren}

Nach etwa einwöchiger Fixierung bei $4^{\circ} \mathrm{C}$ in wässriger Bouin-Lösung wurden die Tumoren in Paraffin fixiert. Zunächst wurden die Tumoren ü.N. bei $4^{\circ} \mathrm{C}$ in $70 \%$ Ethanol gelagert. Am nächsten Tag wurden sie mithilfe einer Paraffineinbettmaschine eingebettet. In dieser Maschine durchlaufen die Tumoren eine Ethanolreihe (70\% für 3 h, $80 \%$ für 1 h, $90 \%$ für 1 h, $96 \%$ für 1 h, 99\% für $2 \mathrm{~h}$ ) und werden anschließend für 1,5 h in Isopropanol belassen. Danach werden die Tumoren nacheinander drei Mal in Xylol überführt (30 min, 45 min, 45 min). Zum Schluss werden die Tumoren für 30 min und danach für $7 \mathrm{~h}$ bei $60^{\circ} \mathrm{C}$ in Paraplast Plus ${ }^{\circledR}$ belassen. Nach Durchlaufen der Paraffineinbettmaschine werden die Tumoren in Metallschalen in flüssiges Paraffin gegossen und zum Auskühlen belassen. Die ausgehärteten Paraffinblöcke können nun mit dem Mikrotom geschnitten und auf Objektträger überführt werden. Die Schnittdicke lag bei $6 \mu \mathrm{m}$. Zur Langzeitsaufbewahrung wurden die Objektträger in die $-20^{\circ} \mathrm{C}$-Truhe umgepackt.

\subsubsection{Haematoxylin-Eosin-Färbungen}

Noch vor dem eigentlichen Färbeprozess wurden die Objektträger mit den Schnitten der Tumoren bei RT für 30 Minuten getrocknet. Die Färbungen wurden maschinell vollzogen. Dabei werden die Tumoren zunächst zweimal für jeweils 5 min in Xylol entparaffiniert und anschließend einer Ethanolreihe (99\%, 96\%, 80\%, 60\%) für je 2 min zugeführt. Nach zweiminütigem Waschen in destilliertem Wasser werden die Tumoren für 4 min in Mayers Hämalaun-Lösung überführt und danach wieder für $1 \mathrm{~min}$ in destilliertem Wasser gewaschen. Es schließt sich ein 15-minütiger Vorgang an, bei dem die Schnitte unter fließendem Leitungswasser weiter ausgewaschen werden. Danach werden die Schnitte für $7 \mathrm{~min}$ in Eosin inkubiert und anschließend wieder 1 min lang in destilliertem Wasser gewaschen. Nach erneuter Ethanolreihe $(60 \%, 80 \%, 96 \%)$ für je 1 min und zweimaliger Inkubation für 2 min in 99\%igem Ethanol werden die Tumoren für $3 \mathrm{~min}$ in Xylol entparaffiniert. Letztlich werden die Schnitte zügig nach Herausnahme aus dem Xylol mit DPX Eindeckmedium und Deckgläsern eingedeckt und zum Trocknen ü. N. bei RT belassen. Nun waren die Schnitte bereit, lichtmikroskopisch analysiert und abfotografiert zu werden. 


\subsection{Charakterisierung von BL2-Zellen nach LEF1-Knockdown}

Um den Einfluss des Transkriptionsfaktors LEF1 auf das Tumorwachstum der BL-2 untersuchen zu können wurden zunächst aus der parentalen Zelllinie BL-2 weitere Zelllinien etabliert, die im Gegensatz zur parentalen BL2-Zelllinie LEF1-defizient sind, d.h. der Proteingehalt dieses Transkriptionsfaktors erniedrigt ist. Dieses ist durch genetische Manipulation mittels viraler Transduktion mit unterschiedlichen shRNAs möglich. Im vorliegenden Fall wurden aus zunächst 5 etablierten LEF1-defizienten BL-Zelllinien die 2 Zelllinien kultiviert, die die deutlichste Reduktion der LEF1-Expression zeigten (BL-2 pGIPZ LEF-1 sh\#A \& sh\#E). Zur Kontrolle des Erfolgs der Etablierung und zur weiteren Charakterisierung der unterschiedlichen Zelllinien wurde der Proteingehalt von LEF1 in den verschiedenen Zelllinien mittels Durchflusszytometrie auf das Green Fluorescence Protein (GFP) überprüft. GFP-positiv sind die transduzierten Zellen, da die Viren die kodierende DNA für dieses Protein mit in das Genom der Zelle integriert haben. Je stärker die Zellen fluoreszieren, desto mehr shRNA sollte in der Zelle exprimiert werden und kann als indirekter Hinweis auf einen erfolgreichen LEF1-KD gewertet werden (siehe Abb. 3-1). Die parentale BL2-Zelllinie (Wildtyp) ist GFP-negativ (siehe Abb. 3-1A). Die genetisch manipulierten Zelllinien weisen alle eine GFP-Expression in unterschiedlicher Fluoreszenzstärke auf (siehe Abb. 3-1B-E). Die Kontroll-Zelllinie BL-2 pGIPZ ctrl 1 zeigt den höchsten GFP-Gehalt, während in den anderen Zelllinien eher eine breitere Fluoreszenz zu beobachten ist, die sich auf zwei Populationen verteilt (siehe Abb. 3-1B-E). Ähnlich sieht es bei der shA-Probe aus, während die Expression von GFP in der shE-Population noch einmal deutlich intensiver ist (siehe Abb. 3-1D-E). Die Kontrollzelllinie ctrl 1 zeigt verglichen mit der Kontrollzelllinie ctrl 2 ebenfalls eine intensivere GFP-Expression (siehe Abb. 3-1B-C). 

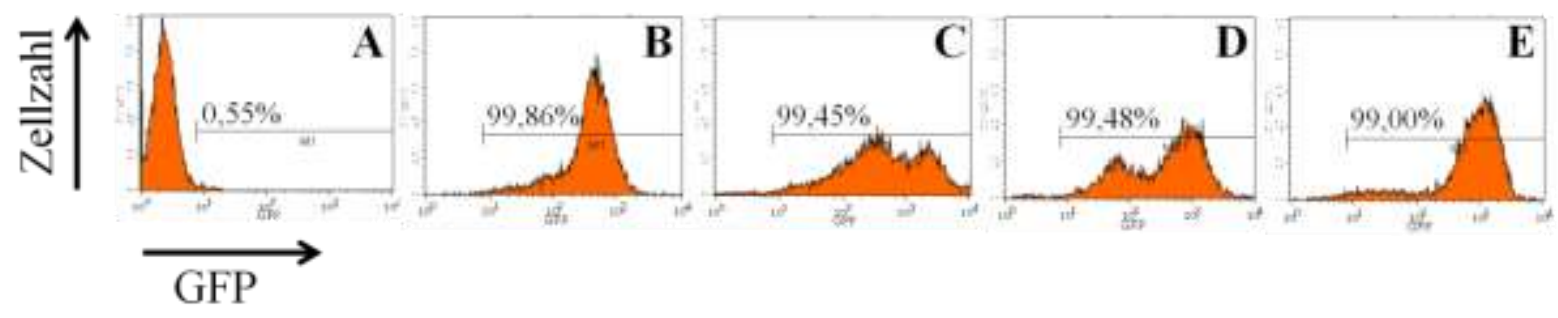

Abb. 3-1: Durchflusszytometrische Analyse der in dieser Arbeit verwendeten Zellen. Dargestellt ist die Zahl der GFP-exprimierenden Zellen (y-Achse) und die Intensität der Fluoreszenzen des GFPProteins (x-Achse). Die Prozentzahlen stellen den Anteil der GFP-exprimierenden Subpopulation dar bezogen auf eine GFP-Schwelle (A) BL2-Zellen, (B) BL-2 pGIPZ LEF-1 ctrl 1, (C) BL-2 pGIPZ LEF1 ctrl 2 sowie (D) BL-2 pGIPZ LEF-1 shA und (E) BL-2 pGIPZ LEF-1 shE.

Der direkte Nachweis des LEF1-KD wurde mittels Immunoblot durchgeführt (siehe Abb. 3-2).

Die Zelllinie BL-2 pGIPZ LEF-1 shA zeigte die deutlichste Reduktion von LEF1.

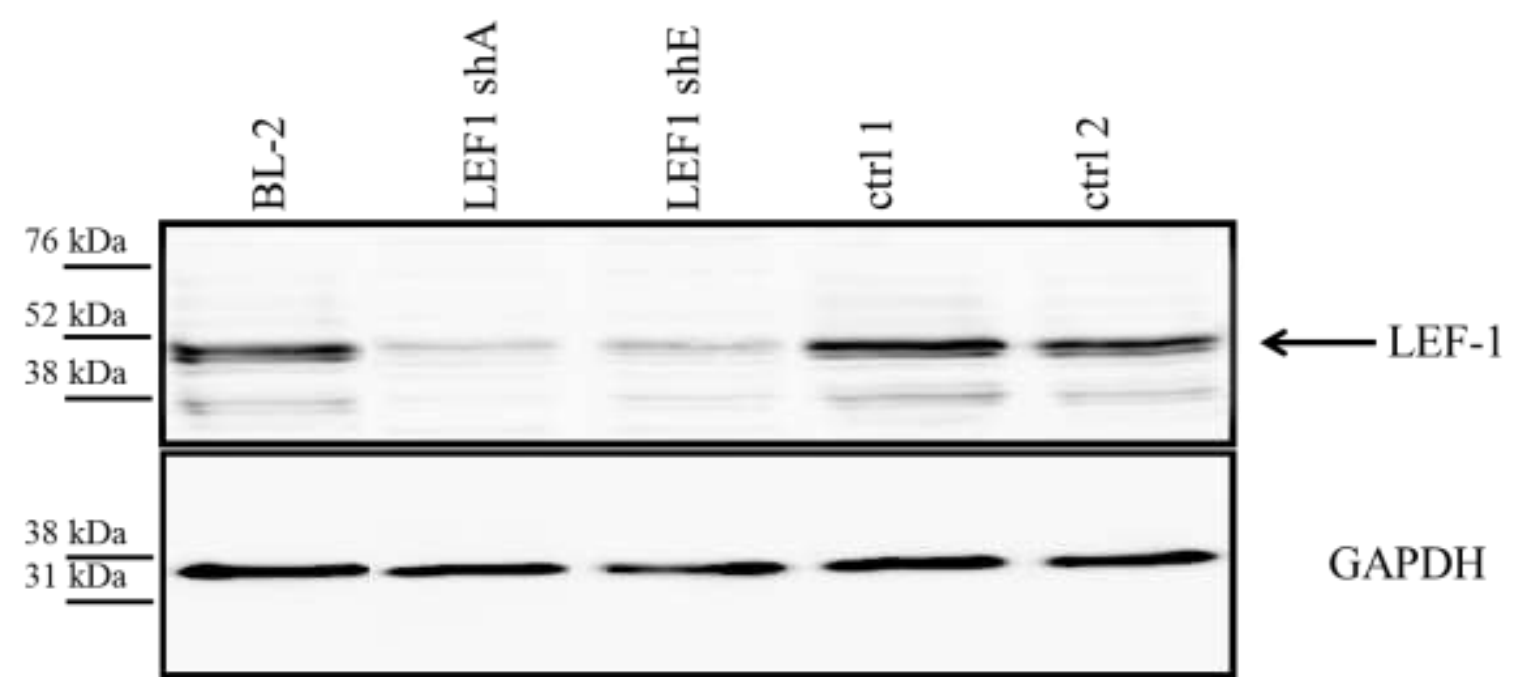

Abb. 3-2: Nachweis der reduzierten Menge von LEF1 mittels Immunoblotanalyse. Von den unterschiedlichen BL2-Zelllinien wurden jeweils identische Proteinmengen aufgetragen und analysiert. Die Zelllinie BL-2 pGIPZ LEF-1 shA zeigte den stärksten Knockdown. Glycerinaldehyd-3-phosphatDehydrogenase (GAPDH) diente als Beladungskontrolle. Die Proteingrößen sind in kDa angegeben. 
Als nächstes wurde die Zellproliferation bei allen verwendeten Zelllinien mittels ${ }^{3} \mathrm{H}$-ThymidinAssay überprüft. Das Ergebnis zeigte, dass hinsichtlich des Wachstums in Kultur kein Unterschied zwischen den verschiedenen Zelllinien bestand (siehe Abb. 3-3). Ähnliche Ergebnisse ergab auch die Analyse der Zellverdopplungszeit, bei der keine Unterschiede zwischen der parentalen BL2, den scrb-shRNA transduzierten und LEF1-shRNA transduzierten BL2-Zellen beobachtet werden konnte.

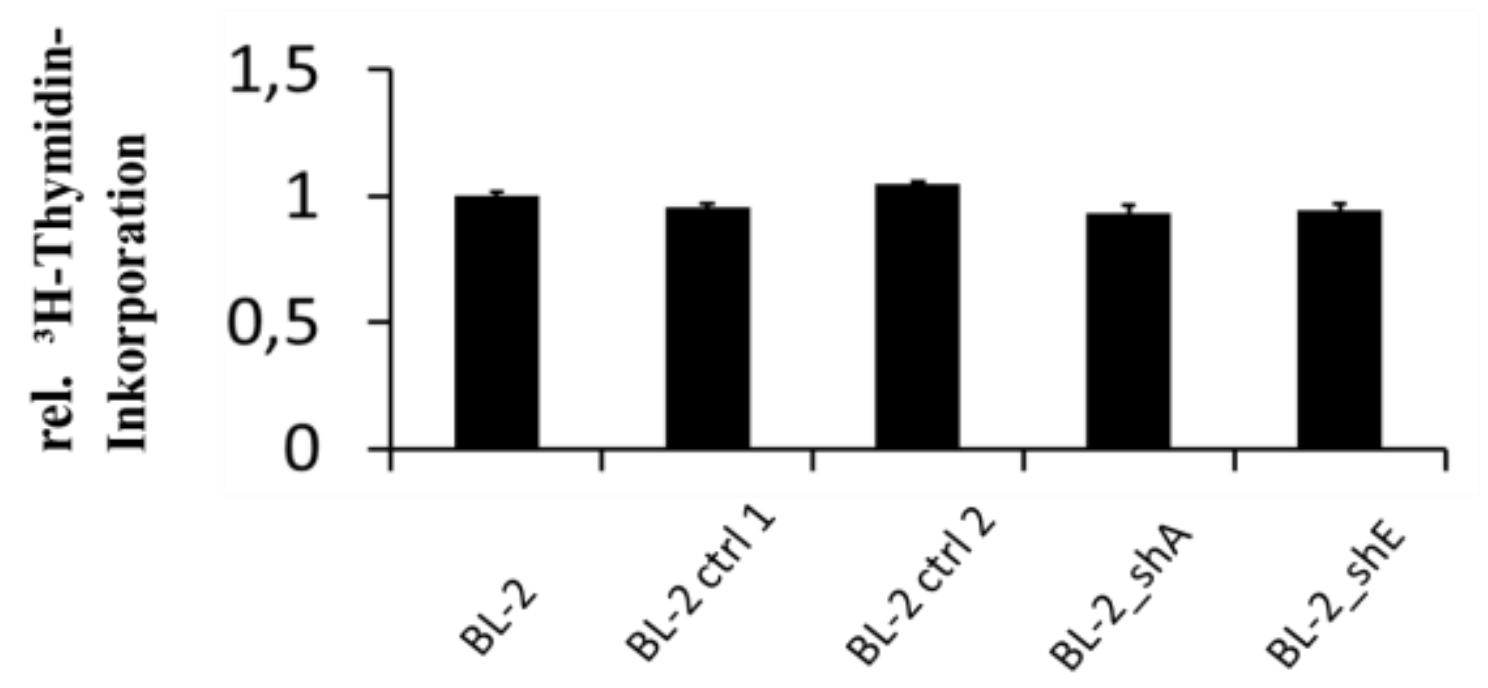

Abb. 3-3: Der stabile LEF-1 Knockdown in BL2-Zellen hat keinen Einfluss auf die Zellproliferation. Die Proliferation wurde innerhalb $24 \mathrm{~h}$ bei den Knockdown-Zelllinien (BL-2 LEF1 shA und shE), den Kontrollen ( $c t r l 1$ und ctrl 2) und der parentalen BL2-Zelllinie mittels ${ }^{3}$ H-ThymidinInkorporation analysiert. Dargestellt sind die Mittelwerte eines repräsentativen Assays. Die Gesamtcounts der BL-2 wurden auf 1 normiert (y-Achse). Die Fehlerbalken beschreiben die einzelnen Variationskoeffizienten.

\subsection{Einfluss von LEF1 auf das Tumorwachstum im Xenograft-Modell}

Da mittels ${ }^{3} \mathrm{H}$-Thymidin-Assay kein Unterschied in der Proliferation zwischen den LEF1aberranten und LEF1-defizienten Burkitt-Lymphom-Zelllinien $\mathrm{zu}$ sehen war, wurden die verschiedenen Zelllinien im Xenograft-Modell getestet, um den Einfluss von LEF-1 auf das Tumorwachstum in vivo zu untersuchen. Insgesamt wurden 3 CAM-Assays mit den BL2Zelllinien durchgeführt. Parallel zu den CAM-Assays wurde jedes Mal der intrazelluläre Proteingehalt von LEF-1 in den verschiedenen Zelllinen mittels Immunoblot-Analyse und Durchflusszytometrie auf GFP überprüft, um den stabilen LEF1-Knockdown sicher zu stellen 
(siehe Abb. 3-1 und 3-2). Pro befruchtetem Hühner-Ei wurden jeweils 2 x $10^{6}$ Zellen in MatriGel auf die CAM aufgetragen. An Tag 4 nach Beimpfung wurden die angewachsenen Tumoren geerntet. Pro CAM-Runde wurde mit jeweils 60 Hühnereiern gestartet. In Runde 1 konnten letztendlich insgesamt nur 38 Xenograft-Lymphome geerntet werden, in Runde 235 Xenograft-Lymphome und in Runde 340 Xenograft-Lymphome. Gründe hierfür sind unbefruchtete Eier und Pilzkontaminationen. Eine Übersicht über die Ausbeute der 113 geernteten Tumoren ist Tabelle 3-1 zu entnehmen. Um eine gewisse Anzahl an Tumoren jeder Zelllinie vorzuweisen wurden bei der parentalen BL-2-Zelllinie zudem 4 Tumoren eines vorherigen CAM-Assays verwendet. Diese Tumoren wurden unter gleichen Bedingungen bebrütet.

Tab. 3-1: Übersicht aller geernteter Tumoren der 3 CAM-Assays. Die 4 zusätzlichen BL2-Tumoren kommen aus dem beschriebenen Vorversuch. In allen 3 CAM-Assays wurden die Tumoren an Tag 4 nach Beimpfung der Tumorzellen auf die CAM geerntet.

\begin{tabular}{|l|l|l|l|l|}
\hline$\underline{\text { Zelllinie }}$ & $\underline{\text { CAM-Runde 1 }}$ & $\underline{\text { CAM-Runde 2 }}$ & $\underline{\underline{\text { CAM-Runde 3 }}}$ & $\underline{\underline{\text { Summe Tumoren }}}$ \\
\hline BL-2 & Nicht beimpft & 4 Tumoren & 1 Tumor & $\begin{array}{c}9 \text { Tumoren } \\
(5+4 \text { Tumore })\end{array}$ \\
\hline $\begin{array}{l}\text { BL-2 pGIPZ } \\
\text { ctrl 1 }\end{array}$ & 10 Tumoren & 6 Tumoren & 9 Tumoren & 25 Tumoren \\
\hline $\begin{array}{l}\text { BL-2 pGIPZ } \\
\text { ctrl 2 }\end{array}$ & 8 Tumoren & 8 Tumoren & 10 Tumoren & 26 Tumoren \\
\hline $\begin{array}{l}\text { BL-2 pGIPZ } \\
\text { LEF1 shA }\end{array}$ & 11 Tumoren & 8 Tumoren & 10 Tumoren & 29 Tumoren \\
\hline $\begin{array}{l}\text { BL-2 pGIPZ } \\
\text { LEF1 shE }\end{array}$ & 9 Tumoren & 9 Tumoren & 10 Tumoren & 28 Tumoren \\
\hline
\end{tabular}

\subsubsection{LEF1-defiziente Xenograft-Tumoren sind kleiner als LEF1-aberrante Tumoren}

Nach Ernte der Tumoren wurden noch am selben Tag Lichtbilder aller Tumoren angefertigt. Bei genauerer Betrachtung fiel auf, dass die LEF1-defizienten Tumoren von ihrer Fläche kleiner wirkten (siehe Abb. 3-6). Zur Objektivierung dieses Eindruckes wurde die Fläche der Tumoren mithilfe der Software ImageJ ausgemessen. Anhand eines vorher bestimmten $1 \mathrm{~cm}-$ 
Scales ist es möglich, die Fläche eines Tumors ausrechnen zu lassen (siehe Abb. 2-4). Das Ergebnis war, dass die LEF1-defizienten Tumoren beträchtlich kleinere Flächen im Durchschnitt besaßen verglichen mit den LEF1-aberranten Tumoren (siehe Tab. 3-2). Die Kontrollzelllinien BL2 pGIPZ ctrl 1 und 2 verhielten sich alles in allem wie die parentale BL2Zelllinie (siehe Tab. 3-2). Das Experiment wurde drei Mal unter gleichen Bedingungen durchgeführt. Die Daten der Experimente werden als Mittelwert \pm Standardabweichung (Mittelwert \pm SD) angegeben. Die Kontrollgruppen und die behandelten Gruppen wurden statistisch mittels t-Test miteinander verglichen. Zuvor wurde durch den KolmogorowSmirnow-Test eine Normalverteilung für alle Gruppen bestätigt. Die Analysen wurden mit GraphPad Prism 5 (GraphPad Software Inc.) durchgeführt.

In den Tabellen 3-2, 3-3 und den Abbildung 3-4, 3-5 und 3-6 sind die tabellarischen Daten und Bildbeweise zusammengefasst. Die Tumoren der Zelllinie BL-2 pGIPZ ctrl 1 zeigten im Durchschnitt die größten Tumorflächen auf der CAM (Tab. 3-2 und Abb. 3-4, 3-5). Die Zelllinie BL-2 pGIPZ LEF1 shA wies die kleinsten Tumoren auf (Tab. 3-2, Abb. 3-4, 3-6). Innerhalb der jeweils untersuchten Lymphomgruppe waren die Flächen nicht signifikant unterschiedlich (Tab3-2).

Tab. 3-2: Mittelwerte der CAM-Tumorflächen. Die Tumoren der Zelllinie BL-2 pGIPZ ctrl 1 zeigten im Durchschnitt die größten Tumorflächen auf der CAM. Die Zelllinie BL-2 pGIPZ LEF1 shA wies die kleinsten Tumoren auf. Die Messung der Lymphomflächen auf der CAM erfolgte wie im Material und Methodenteil dargestellt (siehe Abb. 2-4).

\begin{tabular}{|c|c|c|c|}
\hline$\underline{\text { Zelllinie }}$ & $\begin{array}{l}\text { Anzahl } \\
\text { Tumoren (n) }\end{array}$ & $\begin{array}{l}\text { Mittelwert } \\
\text { Tumorfläche }\left(\mathrm{cm}^{2}\right)\end{array}$ & Standardabweichung \\
\hline BL-2 pGIPZ ctrl 1 & 25 & 0,4200 & 0,1370 \\
\hline BL-2 pGIPZ ctrl 2 & 26 & 0,3840 & 0,1552 \\
\hline BL-2 pGIPZ LEF1 shA & 29 & 0,2469 & 0,1091 \\
\hline BL-2 pGIPZ LEF1 shE & 28 & 0,2905 & 0,09998 \\
\hline BL-2 & 9 & 0,3440 & 0,1464 \\
\hline
\end{tabular}


In Abb. 3-4 sind die Tumorzellflächen jedes einzelnen Tumors und der Mittelwert der zugehörigen BL-Zelllinie dargestellt. Zudem werden die Signifikanzniveaus der signifikant unterschiedlichen BL-Zelllinien gezeigt. Zwischen lentiviral transduzierten LEF1-aberranten und LEF1-defizienten Tumoren ergaben sich immer signifikante Unterschiede. Das größte Signifikanzniveau wurde zwischen dem Mittelwert der größten Tumoren (BL-2 ctrl 1) und dem Mittelwert der kleinsten Tumoren (BL-2 LEF1 shA) erreicht. Das geringste Signifikanzniveau ergab sich zwischen den Mittelwerten der Zelllinien BL-2 ctrl 2 und BL-2 LEF1 shE. Mittlere Signifikanzniveaus ergaben die Vergleiche zwischen den Mittelwerten der Zelllinien BL-2 ctrl 1 und BL-2 LEF1 shE sowie zwischen den Mittelwerten der Zelllinien BL-2 ctrl 2 und BL-2 LEF1 shA. Somit bestätigt dies die These, dass aberrantes LEF1 einen positiven Einfluss auf die Größe der Tumorflächen auf der CAM besitzt. 

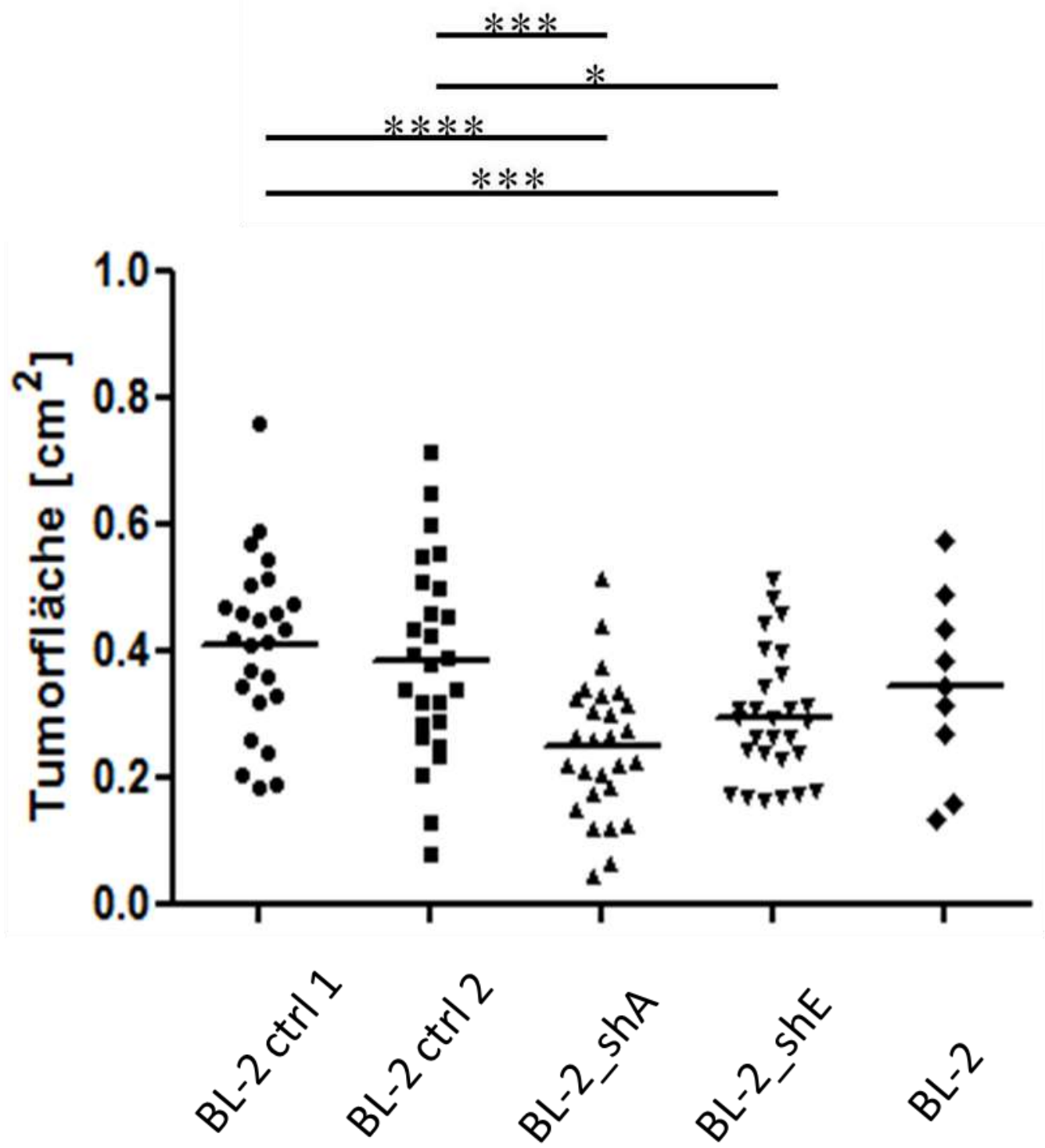

Abb. 3-4: Lymphome mit reduzierter LEF1-Expression sind durch eine geringere Tumorfläche gekennzeichnet. Ergänzende Informationen sind auch in Tab. 3-3 dargestellt. Die Fläche der Tumoren ist in Quadratzentimetern angegeben. Das Signifikanzniveau lag bei *, p<0,05, **, p<0,01, ***, p<0,001, $* * * *, \mathrm{p}<0,0001$. 
Tab. 3-3: Signifikanzen zwischen den jeweiligen Xenograft-Lymphom-Tumorflächen. Innerhalb der jeweiligen LEF1-Gruppen sind keine signifikanten Unterschiede der Tumorflächen zu sehen. Zwischen den jeweiligen LEF1-Gruppen sind signifikante Unterschiede der Tumorflächen zu sehen. Zuvor wurde bei allen beteiligten Zelllinien jeweils eine Normalverteilung mittels KolmogorowSmirnow-Test bestätigt. Das Signifikanzniveau lag bei *, p<0,05, **, p<0,01, ***, p<0,001, ****, $\mathrm{p}<0,0001$.

\begin{tabular}{|c|c|c|c|}
\hline Zelllinie 1 & $\underline{\text { Zelllinie } 2}$ & $\underline{\text { Signifikanz (p-Wert) }}$ & 95\%-Konfidenzintervall \\
\hline BL-2 & $\begin{array}{l}\text { BL-2 pGIPZ } \\
\text { ctrl 1 }\end{array}$ & Nein $\quad(p=0,2302)$ & $-0,1767$ bis 0,04409 \\
\hline BL-2 & $\begin{array}{l}\text { BL-2 pGIPZ } \\
\text { ctrl } 2\end{array}$ & Nein $\quad(p=0,4807)$ & $-0,1627$ bis 0,07823 \\
\hline $\begin{array}{l}\text { BL-2 pGIPZ } \\
\text { ctrl 1 }\end{array}$ & $\begin{array}{l}\text { BL-2 pGIPZ } \\
\text { ctrl 2 }\end{array}$ & Nein $\quad(p=0,5606)$ & $-0,1065$ bis 0,05844 \\
\hline $\begin{array}{l}\text { BL-2 pGIPZ } \\
\text { LEF1 shA }\end{array}$ & $\begin{array}{l}\text { BL-2 pGIPZ } \\
\text { LEF1 shE }\end{array}$ & Nein $\quad(p=0,0922)$ & $-0,008227$ bis 0,1053 \\
\hline $\begin{array}{l}\text { BL-2 pGIPZ } \\
\text { LEF1 shA }\end{array}$ & $\begin{array}{l}\text { BL-2 pGIPZ } \\
\text { ctrl 1 }\end{array}$ & $\mathrm{Ja} * * * * \quad(\mathrm{p}<0,0001)$ & $-0,2316$ bis $-0,09385$ \\
\hline $\begin{array}{l}\text { BL-2 pGIPZ } \\
\text { LEF1 shA }\end{array}$ & $\begin{array}{l}\text { BL-2 pGIPZ } \\
\text { ctrl 2 }\end{array}$ & $\mathrm{Ja} * * * \quad(\mathrm{p}=0,0004)$ & $-0,2126$ bis $-0,06479$ \\
\hline $\begin{array}{l}\text { BL-2 pGIPZ } \\
\text { LEF1 shE }\end{array}$ & $\begin{array}{l}\text { BL-2 pGIPZ } \\
\text { ctrl 1 }\end{array}$ & $\mathrm{Ja} * * * \quad(\mathrm{p}=0,0010)$ & $-0,1799$ bis $-0,04857$ \\
\hline $\begin{array}{l}\text { BL-2 pGIPZ } \\
\text { LEF1 shE }\end{array}$ & $\begin{array}{l}\text { BL-2 pGIPZ } \\
\text { ctrl 2 }\end{array}$ & $\mathrm{Ja}^{*} \quad(\mathrm{p}=0,0135)$ & $-0,1609$ bis $-0,01940$ \\
\hline
\end{tabular}


In Abbildung 3-5 sind exemplarisch Lymphome der BL-2 und der BL2 pGIPZ ctrl 1 dargestellt. $\mathrm{Zu}$ sehen ist, dass zahlreiche kleine Blutgefäße, sowohl in der CAM als auch innerhalb der Tumoren verlaufen. Insgesamt zeigen beide Lymphome bezüglich Tumorfläche, Wachstum und makroskopischem Aussehen starke Ähnlichkeiten.

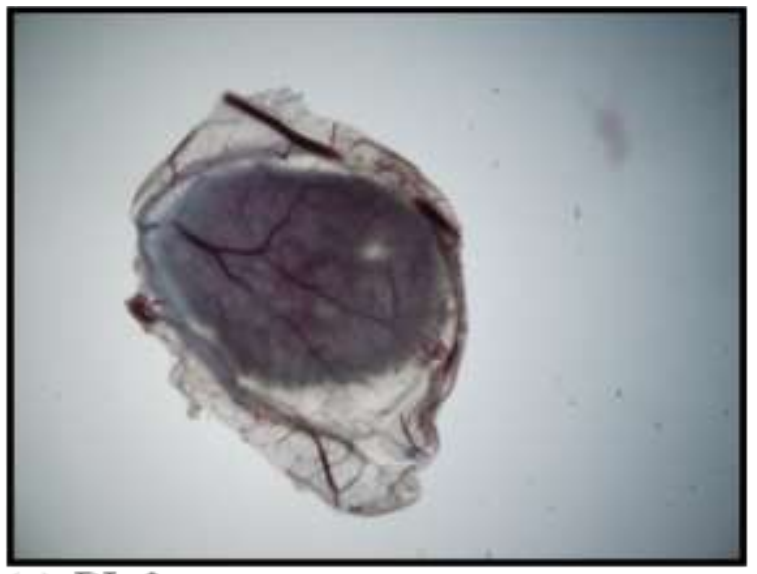

(a) BL-2

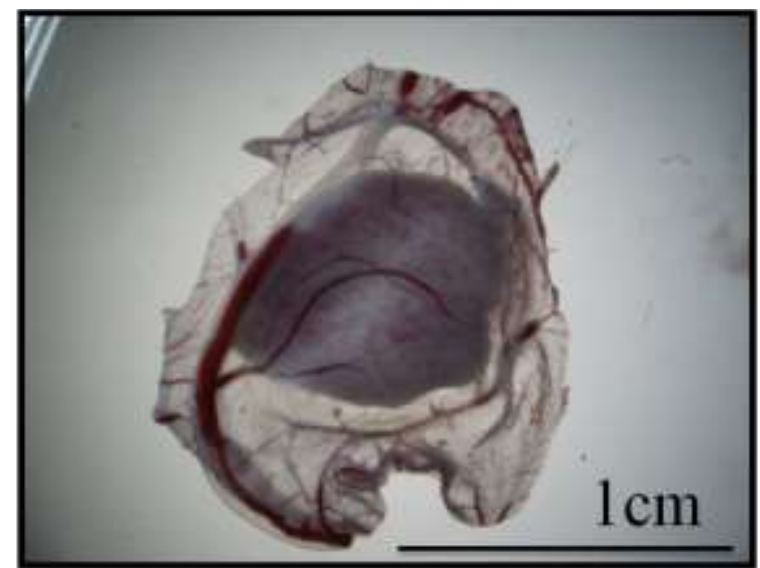

(b) BL-2 pGIPZ ctrl 1

Abb. 3-5: Darstellung repräsentativer Tumoren der parentalen BL2-Zelllinie und der Kontrollzelllinie BL-2 pGIPZ ctrl 1 im Hellfeld. Es ist zu erkennen, dass sich der BL2-Tumor von der Fläche auf der CAM wie der Tumor der Kontroll-Zelllinie BL-2 pGIPZ ctrl 1 präsentiert. Aufnahme der Unterseite der Tumoren.

Im Folgenden werden lichtmikroskopische Aufnahmen der 4 viral behandelten BurkittLymphome gezeigt (siehe Abb. 3-6). Bereits bei makroskopischer Betrachtung sind die Flächenunterschiede zu erkennen. Ein weiterer auffälliger Aspekt der Tumoren waren runde Einblutungen, vor allem bei LEF1-aberranten Tumoren (siehe Abb. 3-6a/b). Allerdings war die Zahl der geernteten Tumoren nicht ausreichend, um signifikante Unterschiede hinsichtlich der Einblutungen zwischen LEF-aberranten und LEF-defizienten Tumoren nachweisen zu können. 


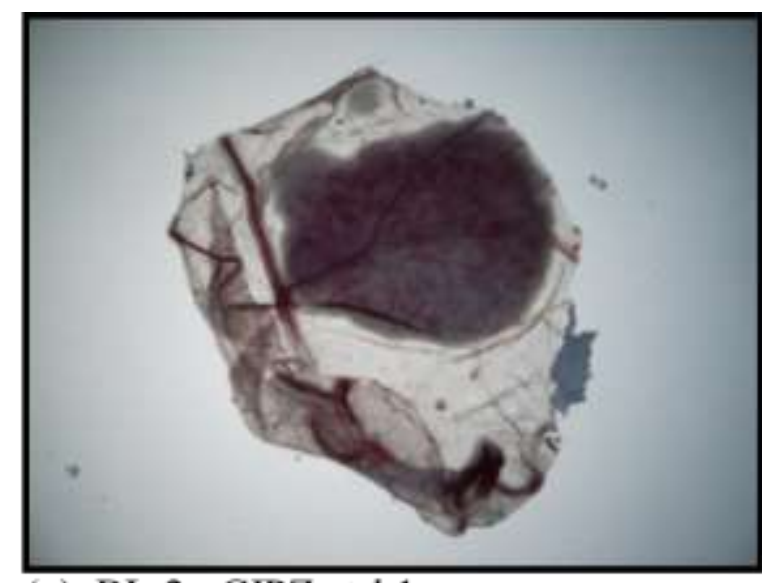

(a) BL-2 pGIPZ ctrl 1

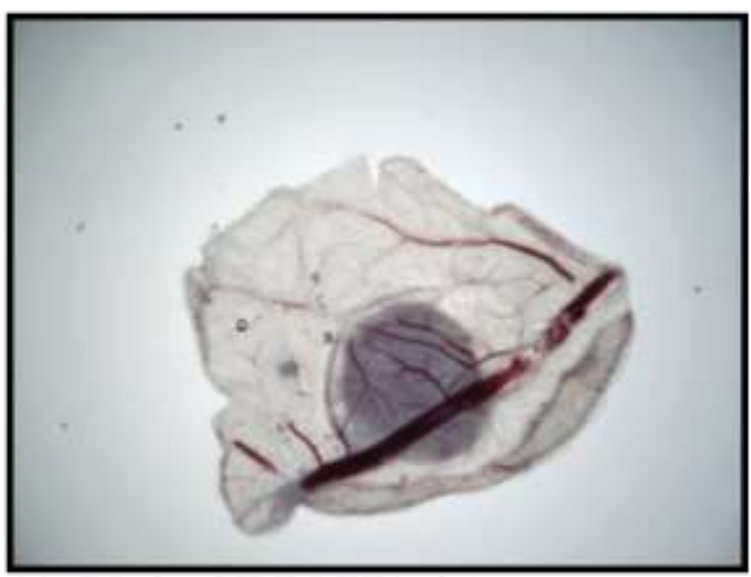

(c) BL-2 pGIPZ LEF1 shA

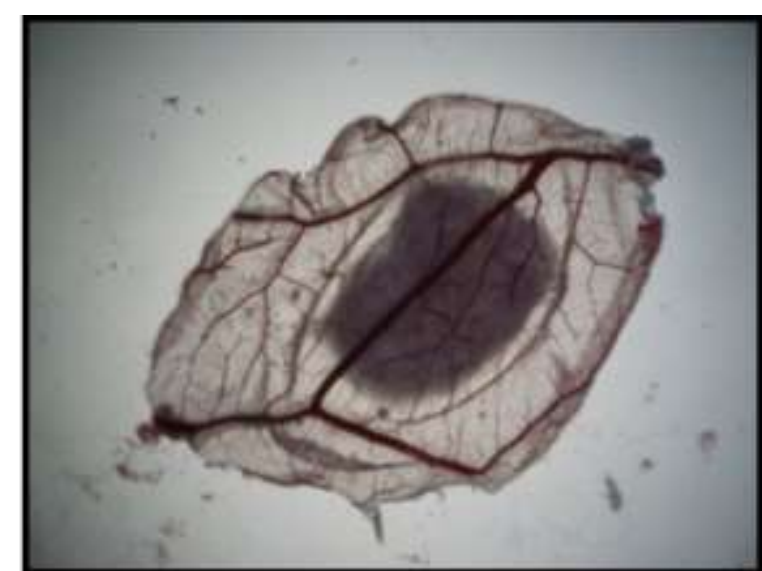

(b) BL-2 pGIPZ ctrl 2

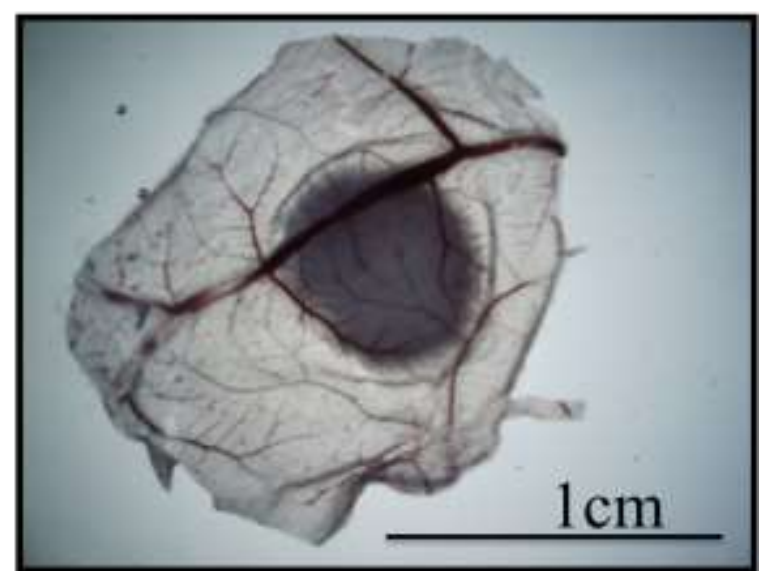

(d) BL-2 pGIPZ LEF1 shE

Abb. 3-6: Darstellung eines Tumors jeder Zelllinie im Hellfeld. Es ist erkennbar, dass die LEF1defizienten Tumoren BL-2 LEF1 shA und shE (c und d) kleinere Flächen auf der CAM aufweisen als die LEF1-aberranten Kontrollen (BL-2 pGIPZ ctrl 1 und ctrl 2, a und b). Die Tumoren wurden direkt nach der Ernte in PBS überführt und anschließend in kleinen Petrischalen abfotografiert. Zuvor wurden pro befruchteten Hühnerei jeweils $2 \times 10^{6}$ Zellen in MatriGel auf die CAM aufgetragen und nach 4 Tagen Inkubation geerntet. Aufnahme der Unterseite der Tumoren.

Somit bestätigt sich das Xenograft-Modell CAM-Assay, um Tumorzellen in ovo anwachsen zu lassen. Zusätzlich sind bereits makroskopisch Wachstums- und Größenunterschiede zwischen LEF1-aberranten und LEF1-defizienten Lymphomen zu erkennen.

Da die kodierende DNA für GFP den viral behandelten Lymphomzellen ins Genom integriert wurde ist es möglich auch Fluoreszenz-Bilder der frisch geernteten CAM-Tumoren mit einem Fluoreszenz-Mikroskop anzufertigen. Dadurch können vor allem die Tumorränder besser beurteilt werden und auch das Wissen über das lokal invasive Einwachsen der Tumoren in die CAM erweitert werden. Zudem kann das lymphogene und hämatogene Metastasierungsverhalten der Tumorzellen näher erforscht werden. Deutlich sichtbar ist, dass 
alle Tumoren an den Rändern Stellen zeigen, die sehr invasive Migration von Tumorzellen in die CAM zeigen (siehe Abb. 3-7). Auch straßenförmige Wanderung von Tumorzellen innerhalb der Lymphgefäße ist klar erkennbar (siehe Abb. 3-7). Deutliche Unterschiede zwischen den jeweiligen Zelllinien gab es jedoch nicht. Die folgenden Abbildungen zeigen einen LEF1defizienten (siehe Abb. 3-7a) und einen LEF1-aberranten Tumor (siehe Abb. 3-7b). Die ausgewählten Stellen zeigen die straßenförmig in die CAM ziehenden lymphogenen Disseminierungen der Tumorzellen, die lymphogene Metastasierungsprozesse vermuten lassen (siehe Abb. 3-7).

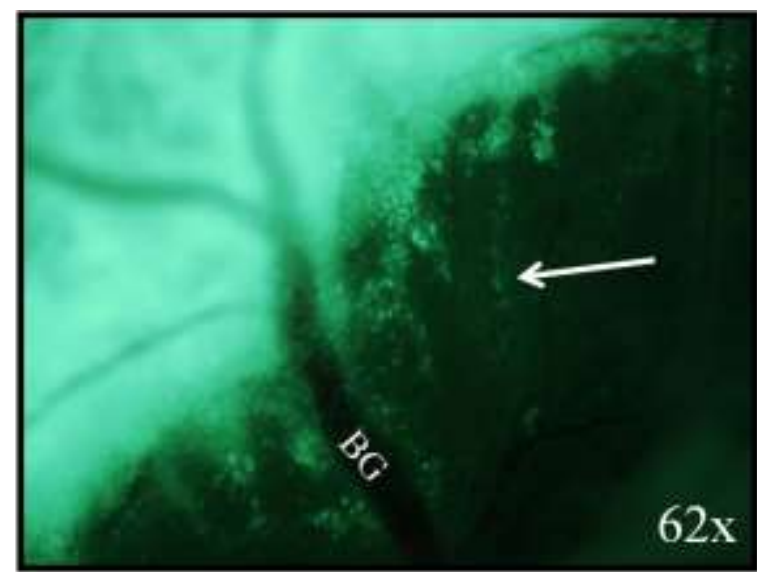

(a) BL-2 pGIPZ ctrl 2

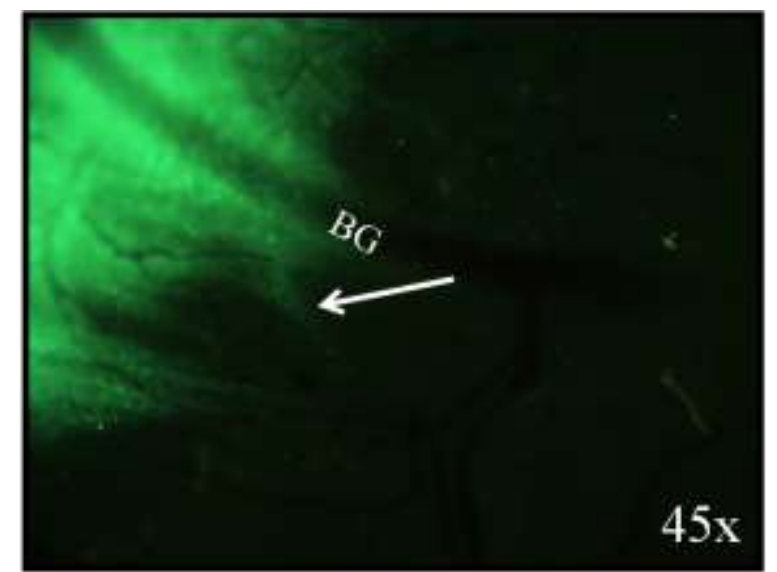

(b) BL-2 pGIPZ LEF1 sh\#A

Abb. 3-7: Fluoreszenzmikroskopische Aufnahmen LEF1-aberranter und LEF1-defizienter Tumorränder zeigen lymphogene Gefäßmigration. Straßenförmige Ausläufer der Tumorzellen in die CAM stellen die lymphogene Gefäßmigration dar (Pfeile). Blutgefäße sind zu erkennen (BG), die jedoch frei von Tumorzellen scheinen. Die Belichtungszeit betrug je 1 Sekunde.

\subsubsection{Histologische Untersuchung der Tumoren}

\subsubsection{Histologie bestätigt Flächenunterschiede zwischen LEF1-aberranten und LEF1- defizienten Lymphomen}

Um ein genaueres histologisches Bild der Tumoren zu bekommen, wurden einige Tumoren in einer Bouin-Lösung fixiert und nach einer Woche Fixierung in Paraffin gegossen, um anschließend geschnitten und gefärbt zu werden. Die Paraffinschnitte ergaben eine schöne Morphologie und viele weitere Erkenntnisse. Die Schnitte wurden mittels HE-Färbung gefärbt. Die Histologie bestätigte den makroskopischen Befund der Flächenunterschiede zwischen den 
Tumoren LEF1-aberranter und LEF1-defizienter Zelllinien. Um die histologischen Präparate besser deuten zu können werden im Folgenden beispielhaft an einem BL2-Lymphom die unterschiedlichen Bestandteile des Tumors erläutert (siehe Abb. 3-8). Der solide Tumor an sich wird durch die proliferierenden Lymphomzellen gebildet, die zuvor auf die CAM pipettiert wurden und sich dort im Bindegewebe (Stroma) der CAM teilen. Die CAM ihrerseits wird außen durch das Chorionepithel und zur Embryo gewandten Seite durch das Allantoisepithel begrenzt. Die CAM ist sehr gefäßreich. Zum einen wird sie von vielen Lymphgefäßen durchzogen, zum anderen von Blutgefäßen, die sich im Bereich des Tumors dann über dem Allantoisepithel aufreihen. Des Weiteren kommen Blutgefäße im Tumor selbst vor.

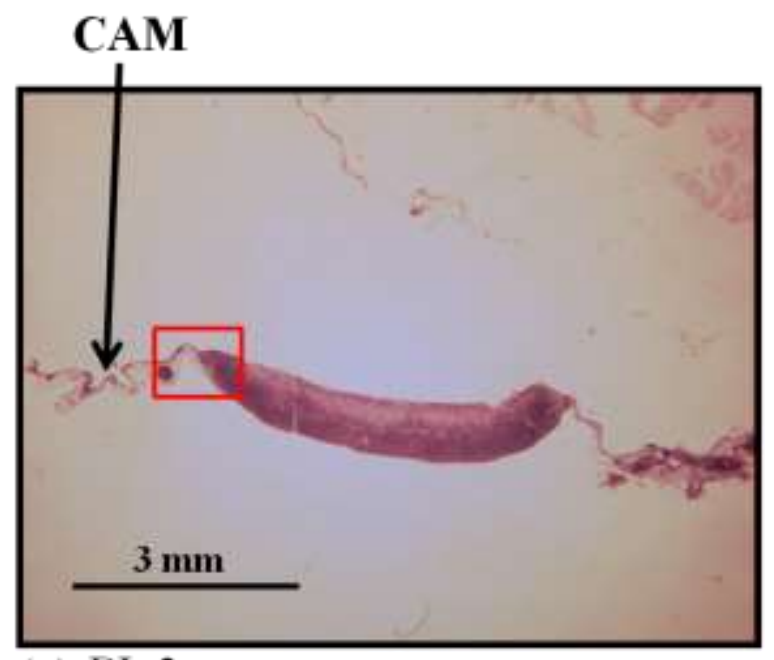

(a) BL-2

\section{Chorionepithel}

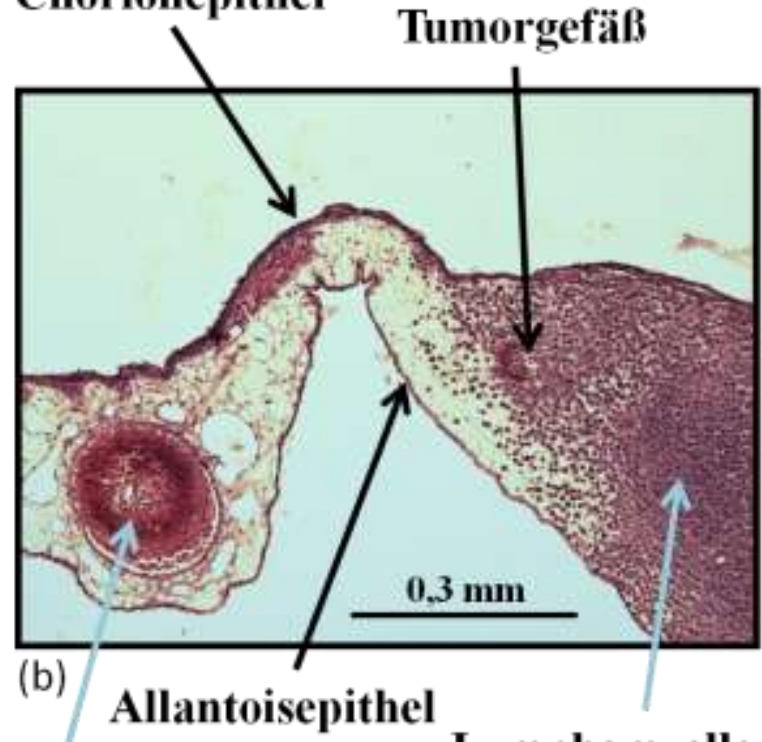

Lymphomzellen präexistentes Blutgefäß

Abb. 3-8: CAM-Lymphom. Der Tumor wurde zuvor für 7 Tage in Bouin-Lösung fixiert, danach in

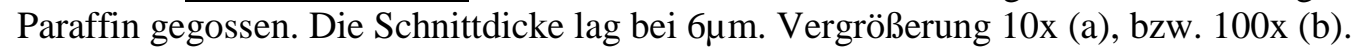

In den HE-gefärbten Paraffinschnitten ist des Weiteren zu sehen, dass sich die Tumorzellen um Blutgefäße zu noch dichteren ringförmigen Anordnungen anordnen (siehe Abb. 3-9). Je größer das Gefäß ist, umso mehr Zellen und umso dichter scheinen die Zellen zu sein. 


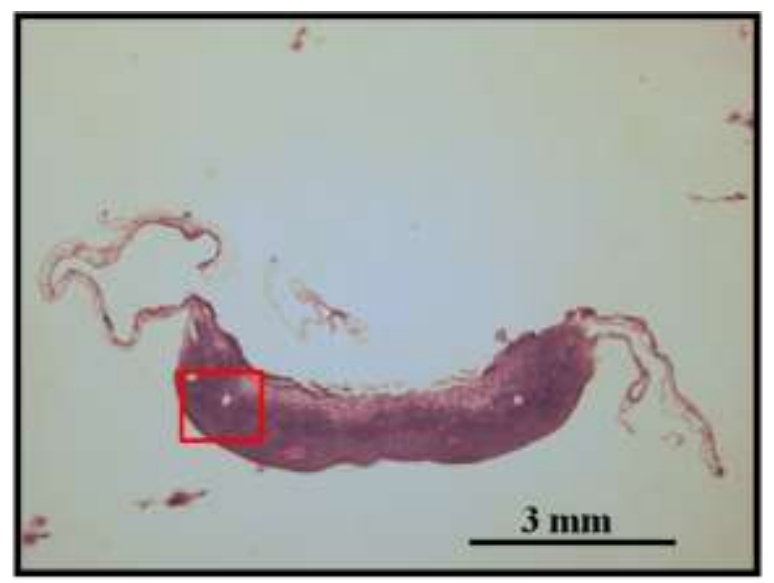

(a) BL-2 pGIPZ ctrl 2

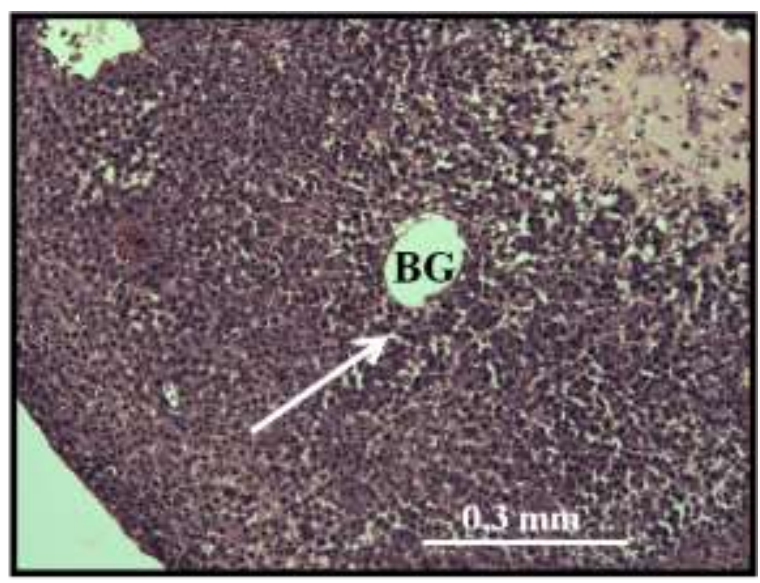

(b)

Abb. 3-9: HE-Schnitte der CAM-Tumoren. Darstellung eines großlumigen Blutgefäßes (BG) innerhalb des Tumors. Es ist zu erkennen, dass sich die Tumorzellen zu einem Ring um das Gefäß anordnen (weißer Pfeil). Innerhalb des Gefäßes ist keine Tumorzelle zu finden. Die Tumoren wurden zuvor für 7 Tage in Bouin-Lösung fixiert, danach in Paraffin gegossen. Die Schnittdicke lag bei $6 \mu \mathrm{m}$. Vergrößerung 10x, bzw. 100x.

Im Folgenden wird ein Tumor der parentalen BL2-Zelllinie dargestellt, die vom Wachstumsmuster eindeutig dem der Kontroll-Zelllinien (BL-2 pGIPZ ctrl 1 und ctrl 2) gleicht (siehe Abb.3-10). Er ist charakterisiert durch seine Kompaktheit und seinen Zellreichtum. Es können keine MatriGel-Reste mehr gefunden werden. Der Tumor wächst flächig in die CAM ein.

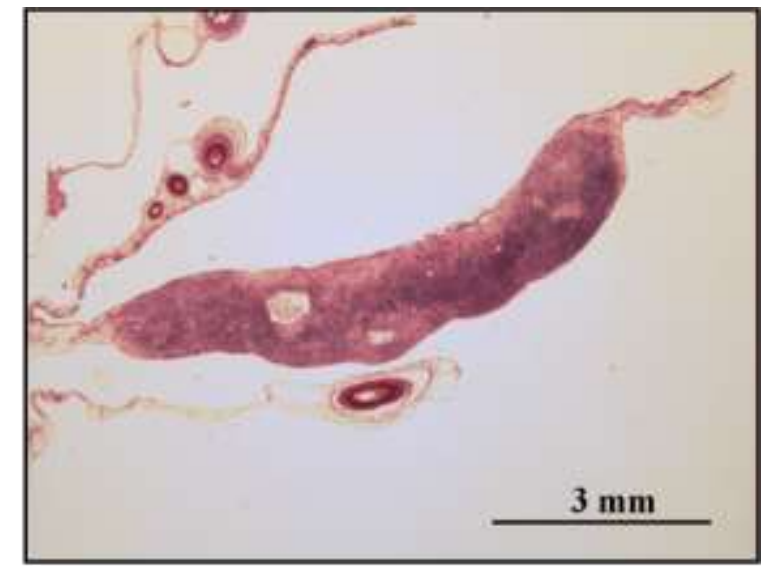

BL-2

Abb. 3-10: HE-Schnitt eines CAM-Tumors der parentalen BL2-Zelllinie. Es zeigt sich ein kompakter und zellreicher Tumor, der flächig in die CAM einwächst. Der Tumor wurde zuvor für 7 Tage in Bouin-Lösung fixiert, danach in Paraffin gegossen. Die Schnittdicke lag bei $6 \mu \mathrm{m}$. Vergrößerung $10 \mathrm{x}$. 
Nun werden repräsentative Tumoren jeder Zelllinie dargestellt (siehe Abb. 3-11). Es ist erkennbar, dass sie LEF1-aberranten Tumore ctrl 1 und ctrl 2 von ihrer Morphologie der parentalen BL2-Lymphomen stark ähneln. Die LEF1-defizienten Lymphome wiederrum zeigen ein eher kugeliges Wachstumsmuster. Dies führt auch dazu, dass sie deutlich kleinere Tumorflächen auf der CAM aufweisen. Aber auch die Tumorzellzahl insgesamt scheint stark erniedrigt im Vergleich zu den LEF1-aberranten Lymphomen.

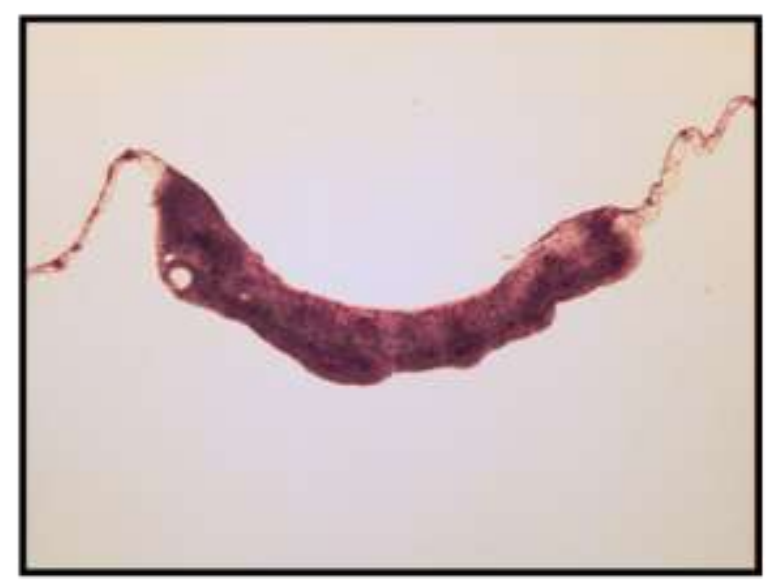

(a) BL-2 pGIPZ ctrl 1

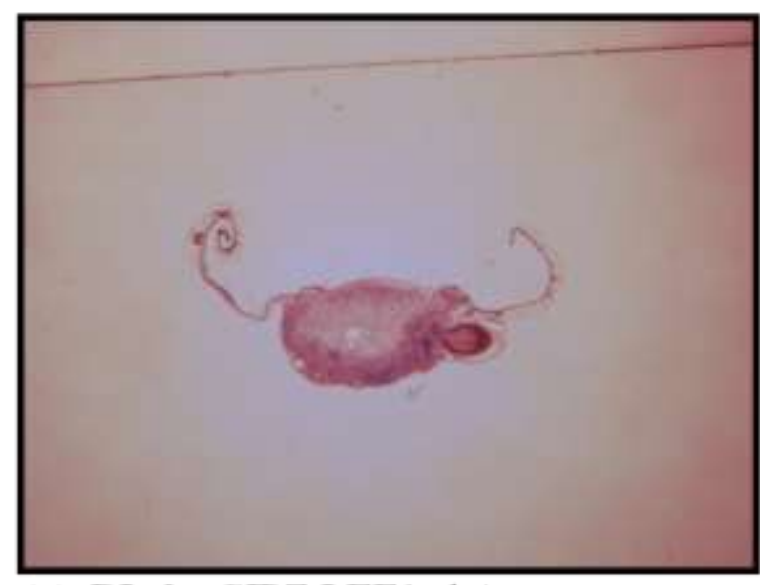

(c) BL-2 pGIPZ LEF1 shA

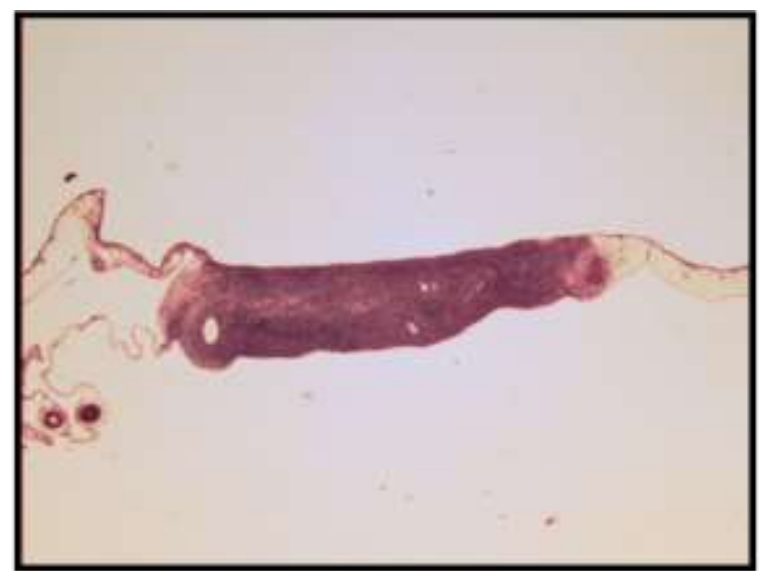

(b) BL-2 pGIPZ ctrl 2

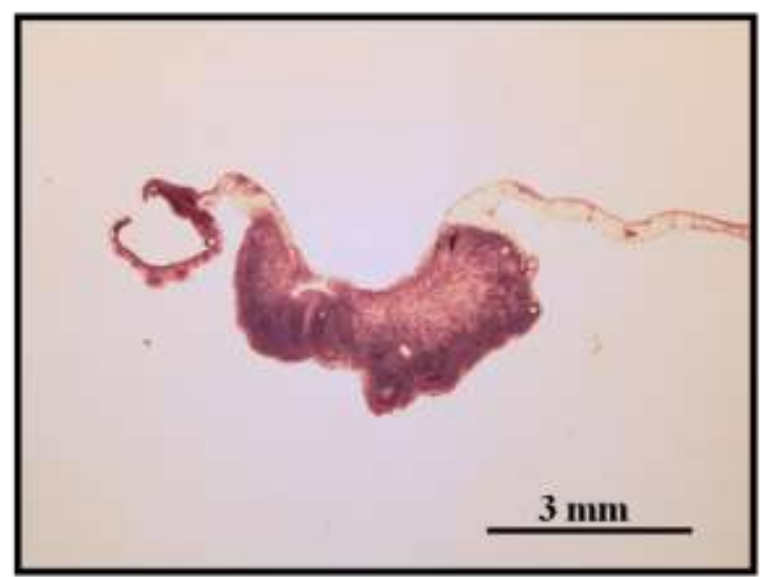

(d) BL-2 pGIPZ LEF1 shE

Abb. 3-11: HE-Schnitte der CAM-Tumoren. Die Tumoren der LEF1-defizienten Zelllinien BL-2 pGIPZ LEF1 shA und shE (c und d) zeigen eine deutlich geringere Tumorfläche. Dies ist auch einem eher kugeligen Wachstumsmuster geschuldet. Die Tumoren der Kontroll-Zelllinien (ctrl 1 und ctrl 2, a und b) wirken kompakter und zellreicher. Sie wachsen flächig in die CAM ein. Zuvor wurden die Tumoren für 7 Tage in Bouin-Lösung fixiert und anschließend in Paraffin gegossen. Die Schnittdicke lag bei $6 \mu \mathrm{m}$. Vergrößerung 10x. 


\subsubsection{LEF1-defiziente Tumoren zeigen gehemmte Infiltration der CAM}

Bei größerer Vergrößerung ist zudem erkennbar, dass insgesamt die Infiltration der CAM durch Lymphomzellen bei den LEF1-defizienten Tumoren gehemmt scheint. Vor allem ist dies daran zu sehen, dass größere Bereiche der CAM auch unterhalb des eigentlichen soliden Tumors noch ursprünglich erhalten sind (siehe Abb. 3-12a), hingegen bei den Tumoren der KontrollZelllinien ctrl 1 und ctrl 2 an diesen Stellen zellreicher Tumor zu finden ist (siehe Abb. 3-12b). Die CAM wurde von diesen Tumoren vollständig destruiert und damit aufgelöst. Auch zu den Seiten scheinen diese Tumoren schneller und horizontal flächig in die CAM einzudringen.
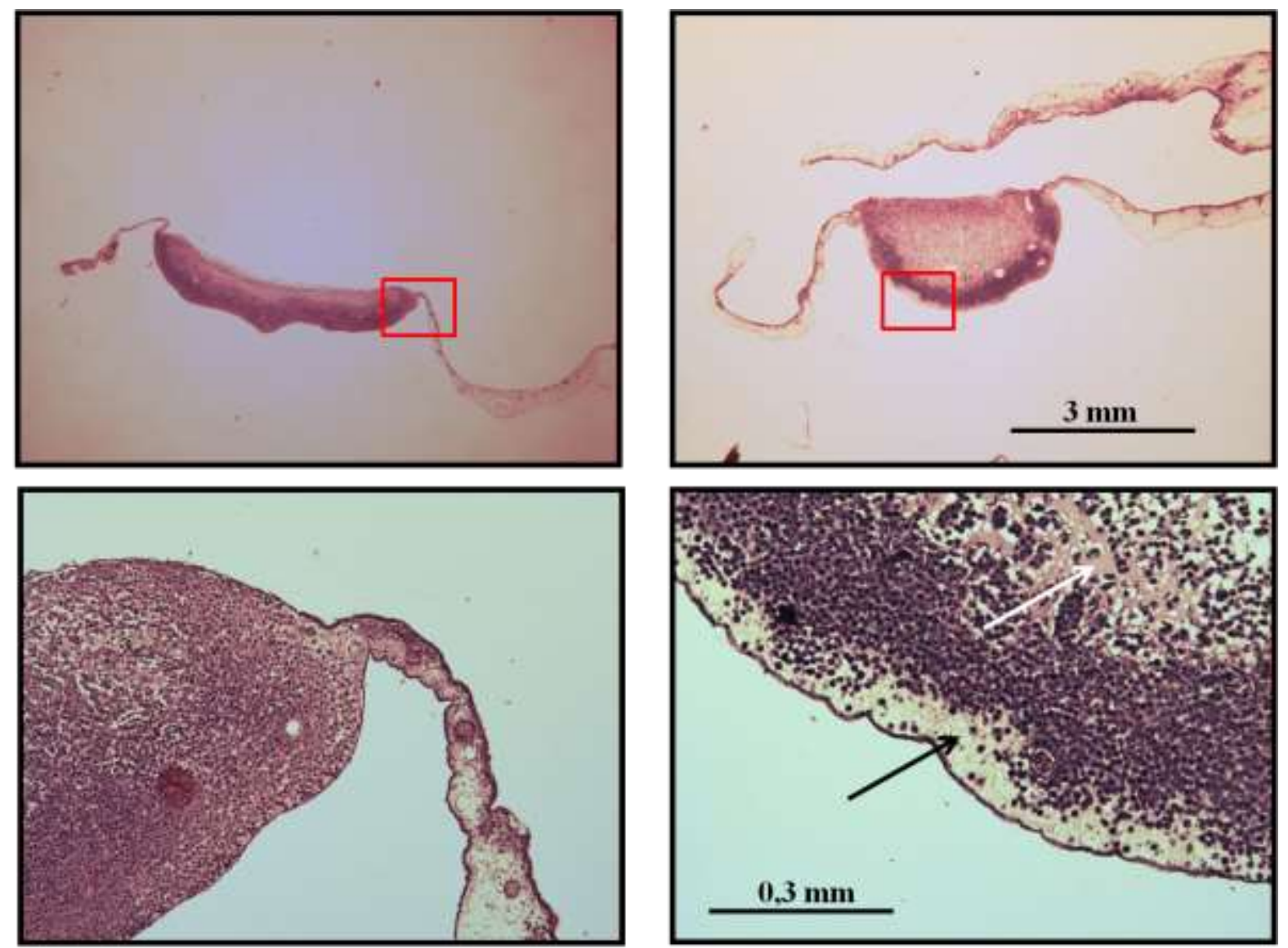

(a) BL-2 pGIPZ ctrl 1

(b) BL-2 pGIPZ LEF1 shA

Abb. 3-12: LEF1-defiziente Lymphome zeigen gehemmte Infiltration der CAM. Unterhalb des dünnen Tumorzellbandes ist die CAM noch erhalten (b, schwarzer Pfeil). Oberhalb des Tumors sind Reste des rosa MatriGels zu erkennen (b, weißer Pfeil), in dem nur vereinzelt Lymphomzellen zu finden sind. Die CAM LEF1-aberranter Lymphome ist vollständig durch Infiltration der Tumorzellen verschwunden (a). Die Tumorzellen treten wesentlich dichter auf. Die Tumoren wurden zuvor für 7 Tage in Bouin-Lösung fixiert und anschließend in Paraffin gegossen. Die Schnittdicke lag bei $6 \mu \mathrm{m}$. Vergrößerung 10x, bzw. 100x. 
Des Weiteren fällt auf, dass die Tumoren der LEF1-defizienten Zelllinien wesentlich zellärmer wirkten, sprich die Zelldichte eine viel Geringere war. Dies ist auch daran zu sehen, dass die Tumoren der LEF1-aberranten Zelllinien in der HE-Färbung wesentlich farbintensiver, dunkler, basophiler aussehen (siehe Abb. 3-11). Ein weiterer auffälliger Punkt ist der Unterschied im Wachstumsmuster. Tumoren der LEF1-defizienten Zelllinien wirken makroskopisch wie auch mikroskopisch kugeliger. Die Tumoren der Kontroll-Zelllinien (ctrl 1 und ctrl 2) hingegen wachsen kompakt flächig in die CAM ein (siehe Abb. 3-12). Ebenfalls erkennbar ist, dass bei Tumoren der LEF1-defizienten Zelllinien erheblich mehr MatriGel-Reste über dem Tumor zu finden sind. Diese Bereiche wirken bei diesen Tumoren spongiotisch und sind besonders zellarm (siehe Abb. 3-12b). Anscheinend wird das MatriGel, was eine Art Ersatz extrazellulärer Matrix auch mit Ernährungsfunktion darstellt, von den LEF1-defizienten Tumorzellen schlechter verdaut. Reste von MatriGel sind hingegen bei den Kontroll-Tumoren (ctrl 1 und ctrl 2) nicht mehr zu finden (siehe Abb. 3-12a). 
Vorarbeiten der Arbeitsgruppe konnten LEF1-aberrante Expression in Tumoren von BurkittLymphomzelllinien zeigen. Zudem konnten diese Zelllinien als ein geeignetes Modell für die Erforschung der Rolle von LEF1 im BL etabliert werden (Walther et al, 2013). Durch transienten LEF-1 Knockdown (KD) wurden in vitro Zielgene des Transkriptionsfaktors LEF1 entdeckt und weiter beschrieben (Walther et al, 2013).

In dieser Arbeit sollte unter Verwendung stabil transduzierter LEF1-KD-BurkittLymphomzellen (BL-2) die Funktion von LEF-1 im Xenograft-Modell CAM-Assay charakterisiert werden. Des Weiteren sollte die biologische Wirkung von LEF-1 im Hinblick auf eine mögliche Tumorentstehung untersucht werden. Dabei wurde das Augenmerk zunächst besonders auf Tumorwachstum, Zellmigration und Invasivität gerichtet. Zuerst mussten die zur Verfügung gestellten, viral behandelten Lymphomzellen jedoch weiter etabliert und charakterisiert werden und sich das Xenograft-Modell CAM-Assay als geeignetes Modell erweisen. Die stabile Transduktion an sich stellte schon einen Fortschritt dar, da es bei diesem Vorgehen nicht, so wie in Vorarbeiten mit LEF1-KD-Zelllinien, zu einer Modifikation der Tumorzellen kam. Die viral behandelten BL2-Zellen mussten regelmäßig auf ihren LEF1Gehalt überprüft werden. Letztendlich lässt sich sagen, dass die Etablierung dieser Zellen und weitere Charakterisierung fortgeführt werden konnte (siehe Abb. 3-1, 3-2 und 3-3).

Das Xenograft-Modell CAM-Assay bewies sich als geeignetes Modell zur Erforschung der LEF1-aberranten und LEF1-defizienten Burkitt-Lymphome. Die CAM-Assay-Versuche ergaben, dass LEF1-defiziente Tumoren kleinere Tumorflächen auf der CAM besaßen als LEF1-aberrante Tumoren (siehe Abb. 3-4). Auch ihre Tumorzellzahl und Zelldichte war eine geringere. Dass dies nicht an einer zugrunde liegenden gesteigerten Zellproliferation der LEF1aberranten Lymphomzellen in Kultur lag, wurde zuvor durch den ${ }^{3} \mathrm{H}$-Thymidin-Assay überprüft (siehe Abb. 3-3). Dennoch könnte eine erhöhte Zellproliferation der LEF1-aberranten Lymphome in ovo eine Erklärung für die Flächenunterschiede und Wachstumscharakteristika sein. Dieser Aspekt müsste in Zukunft durch Färbungen auf der CAM mit Proliferationsmarkern (Ki-67 etc.) überprüft werden. Viele Vorarbeiten unterstützen die These, dass aberrantes LEF-1 mit gesteigerter Tumorzellproliferation assoziiert ist. So konnte gezeigt werden, dass aberrantes LEF-1 die Proliferation in Nierenzellkarzinom-Zellen in vivo antreibt (Shang et al, 2014). Die Frage ist, ob die Flächenunterschiede lediglich auf eine gesteigerte Proliferation der LEF1-aberranten Zellen zurückzuführen war oder ob das Anwachsen der Lymphomzellen in der CAM erschwert war. Denn das fremde Milieu der CAM stellt eine 
schwierige Umgebung für die Tumorzellen zum Anwachsen dar. Der Aspekt der LEF1unterstützten Tumorinitiation konnte von Petersson in seiner Arbeit zu Tumoren der menschlichen Talgdrüse gezeigt werden (Petersson et al, 2015).

Die Hypothese, dass LEF-1 möglicherweise Tumorinitiation und Zellproliferation positiv beeinflusst, bleibt bestehen. Insgesamt jedoch erscheint es aus Sicht dieser Arbeit eher unwahrscheinlich, dass die Proliferation der Tumorzellen für die beobachteten Flächenunterschiede verantwortlich ist.

Näherliegende Aspekte zielen auf Zellmigration und Invasivität der Lymphomzellen sowie den Einfluss der Tumorzellen auf das Microenvironment. Dabei muss darauf geachtet werden, dass Tumorzellmigration und Invasivität getrennt voneinander betrachtet werden. Eine gesteigerte Migrationsneigung LEF1-aberranter Lymphomzellen sowie auch eine gesteigerte Invasivität könnte zu größeren Tumorzellflächen auf der CAM geführt haben. Arbeiten zum Glioblastoma multiforme konnten zeigen, dass LEF-1 die Zellmigration wie auch die Tumorinvasion fördert (Gao et al, 2014). Auch Arbeiten zum Prostatakarzinom ergeben Hinweise zur LEF1getriggerten Tumorinvasion (Liang et al, 2015). Alles in allem ergeben sich somit Hinweise, dass aberrantes LEF1 die Tumorzellmigration und die Invasivität der Tumorzellen reguliert. Die geringere Matrixdestruktion von LEF1-defizienten Lymphomzellen zeigt am augenscheinlichsten mögliche Einflüsse von LEF-1 auf Zellmigration, Invasivität und den Einfluss der Tumorzellen auf das Microenvironment (siehe Abb. 3-12b). LEF1-aberrante Lymphomzellen hingegen konnten das MatriGel komplett zersetzen (siehe Abb. 3-12a). Dadurch könnten auch die Unterschiede in der Tumormorphologie erklärt werden. Eine Möglichkeit wäre, dass LEF1 einen regulierenden Einfluss auf das Remodelling des Tumormicroenviroments, das in diesem Falle durch das MatriGel aufgebaut wurde, hat. Denn offensichtlich war diese Interaktion bei LEF1-defizienten Lymphomzellen gestört. Jedoch auch dieser Aspekt müsste in Zukunft noch hinreichend geklärt werden. Die Unterschiede zwischen LEF1-aberranten und LEF1-defizienten Burkitt-Lymphomen im Hinblick auf die Matrixdestruktion geben Hinweise über mögliche Regulationsprozesse von MatrixMetalloproteinasen (MMP) und/oder Angiopoetinen. Diese Hypothesen sollten in Zukunft jedoch ebenfalls Gegenstand wissenschaftlicher Forschung sein. Mit Augenmerk auf die Regulation von Matrix -Metalloproteinasen konnte eine Arbeit zeigen, dass eine LEF1Defizienz in menschlichen Endothelzellen das basale Level von MMP-2 reduziert und somit die Vermutung besteht, dass LEF1 höhere MMP2-Level fördert (Planutiene et al, 2009). Auch 
die Zellinvasion konnte durch LEF1-Überexpression drastisch gesteigert werden im Rahmen der genannten Arbeit (Planutiene et al, 2009).

Des Weiteren fällt das gesehene Phänomen der runden Einblutungen, vor allem bei LEF1aberranten, auf (siehe Abb. 3-6a/b). Diese ergeben Hinweise auf mögliche Einflüsse von LEF1 auf die Regulation von Vascular Edothelial Growth Factors (VEGF A, C, D) und stellen somit einen Unterpunkt des möglicherweise LEF1-assoziierten TumormicroenvironmentRemodellings dar. Die Zahl der Tumoren und Einblutungen war jedoch nicht hoch genug, um hinsichtlich der Einblutungen signifikante Unterschiede zwischen LEF-aberranten und LEFdefizienten Tumoren feststellen zu können. Ein Fokus folgender Arbeiten könnte darauf liegen, die Einblutungen zwischen LEF-aberranten und LEF-defizienten Tumoren zu quantifizieren und statistisch auszuwerten. Im Hinblick auf den Einfluss von LEF-1 auf VEGFs gibt es leider noch sehr wenig Hinweise. Eine Arbeit konnte zeigen, dass der LEF1-abhängige WntSignalweg in Maus -und Zebrafischzellen unter anderem die Stabilität von neuen Blutgefäßverbindungen kontrolliert und somit auch die Gefäßdichte bei der Angiogenese (Phng et al, 2009). Ob LEF-1 einen positiven Einfluss auf Tumorneoangiogenese ausübt bzw. ob eine LEF-Defizienz zur Degression der Tumorvaskularisierung führt, bleibt jedoch sehr hypothetisch.

Zuletzt ergab sich in dieser Arbeit der Eindruck, dass sich die Lymphomzellen vermehrt um Blutgefäße, vor allem größere Blutgefäße, ansammeln (siehe Abb. 3-9). Es kommt vermutlich zu einer Interaktion von Zellen der Blutgefäße mit den Zellen der Lymphom-Zelllinien (Vessel co-option). Bei diesem Punkt ergibt sich die Frage nach Einflüssen von LEF-1 auf den Metabolismus und die Ernährung der Tumorzellen. Eine mögliche Hypothese wäre, dass LEF1 Prozesse reguliert, die einen Überlebensvorteil für LEF1-aberrante Lymphomzellen, auch in schwieriger Umgebung, bedeuten. Invasion in Blutgefäße konnte bei keinem Tumor nachgewiesen werden, wobei dies eventuell zu einem späteren Zeitpunkt des Tumorwachstums stattgefunden haben könnte. In dieser Arbeit wurde der Tag der Tumorernte jedoch so früh gewählt, damit mögliche Unterschiede LEF1-aberranter -und defizienter Tumoren im Hinblick auf das Anwachsen der Tumoren auf der CAM, die Proliferation und die Migration möglichst gut entdeckt werden konnten. 


\section{$5 \quad$ Zusammenfassung}

Da aufgrund der limitierten Erkenntnisse über die Biologie der hoch-aggressiven BurkittLymphome immer noch in vielen Fällen keine Heilung möglich ist, ist es umso wichtiger, mögliche Therapieansätze $\mathrm{zu}$ identifizieren. Ein möglicher Ansatzpunkt ist der Transkriptionsfaktor LEF-1, der in BL-Zellen aberrant exprimiert wird. Dafür allerdings müssen noch viele weitere Erkenntnisse über die Funktion von LEF1 im Burkitt-Lymphom gewonnen werden.

In dieser Arbeit konnte die weitere Etablierung und Charakterisierung der LEF1-KD sowie der scrb-shRNA-BL2-Zelllinien fortgeführt werden. Des Weiteren hat sich das Xenograft-Modell CAM-Assay als geeignetes Modell für die Erforschung LEF1-aberranter und LEF1-defizienter Burkitt-Lymphome erwiesen.

Im Hinblick auf die biologische Funktion von LEF1 in den BL2-Zellen konnten in ovo signifikant kleinere Tumorflächen der LEF1-defizienten Burkitt-Lymphome im Vergleich zu den LEF1-aberranten Burkitt-Lymphomen entdeckt werden.

Aus dieser Erkenntnis konnte hinsichtlich zugrunde liegender Tumoreigenschaften wie dem Anwachsen der Tumoren und der Zellproliferation lediglich die Vermutung gestellt werden, dass LEF1 positiv regulierende Einflüsse auf diese Aspekte ausübt. Näherliegende Hinweise ergaben sich in Bezug auf positiv regulierende Einflüsse von LEF1 auf Migration und Invasivität der Lymphomzellen. Denn das Tumormicroenvironment, welches durch das MatriGel aufgebaut wurde, konnte von LEF1-aberranten Lymphomzellen deutlich besser zersetzt werden. 


\section{Abkürzungsverzeichnis}

A. Bidest.............. bidestilliertes Wasser

ALL .................... akute lymphatische Leukämie

APC adenomatous-polyposis-coli-Protein

BL Burkitt-Lymphom

BSA bovine serum albumin

CAM Chorion-Allantois-Membran

CLL chronisch lymphatische Leukämie

$\mathrm{CO}_{2}$ carbon dioxide

DLBCL diffus großzelliges B-Zell-Lymphom

DMSO Dimethysulfoxid

EBV Epstein-Barr-Virus

FACS fluorescence-activated cell sorting

$\mathrm{g}$ Erdbeschleunigungskonstante $\left(\mathrm{g}=9.80665 \mathrm{~m} / \mathrm{s}^{2}\right)$

FCS fetal calf serum

GAPDH Glycerinaldehyd-3-phosphat-Dehydrogenase

GFP green fluorescent protein

GSK-3ß Glykogensynthase-Kinase 3ß

HIV Humanes Immundefizienz-Virus

HE Hämatoxylin-Eosin

HRP horse radish-Peroxidase

$\mathrm{KD}$ Knockdown

LDH. Laktatdehydrogenase

LEF lymphoid enhancer-binding factor-1 (Protein)

$L E F$ lymphoid enhancer-binding factor-1 (Gen)

LRP LDL-Rezeptor-ähnliches Protein mRNA messenger ribonucleic acid

NHL Non-Hodgkin-Lymphom

OD 595 optische Dichter bei einer Wellenlänge von $595 \mathrm{~nm}$

PBS phosphate buffered salin 
PMSF.

phenylmethylsulfonylfluorid

RIPA radio immuno percipitation assay

RT Raumtemperatur

SDS sodium dodecyl sulfate

SDS-PAGE SDS-Polyacrylamidgelelektrophorese

shRNA short-hairpin ribonucleic acid

TBS tris-buffered saline

TBS-T TBS-Tween

TCF $T$ cell factor

TEMED $N, N, N \backslash N$, -tetramethyl-ethane-1,2-diamin

UTR untranslatierte Region

WHO World Health Organization 
Abb. 1-1: Schematische Darstellung zentraler Elemente des kanonischen Wnt-Signalweg (aus: Rassow et al. 2012).

Abb. 1-2: Ein Embryo in einem Hühnerei (Schema). (modifiziert nach: The Amniote Egg, 2007) .7

Abb. 2-1: Inkubation der Eier im Brutschrank und Freilegen der CAM durch Sägen eines Fensters .24

Abb. 2-2: Blick auf die CAM an Tag 11 der Embryonalentwicklung. Die CAM ist bereits stark vaskularisiert. .25

Abb. 2-3: Ernte der Tumoren und Aufbewahrung in Petrischalen mit PBS.................26

Abb. 2-4: Flächenbestimmung eines CAM-Tumors mithilfe von ImageJ...........................26

Abb. 3-1: Durchflusszytometrische Analyse der in dieser Arbeit verwendeten Zellen..........29

Abb. 3-2: Nachweis der reduzierten Menge von LEF1 mittels Immunoblotanalyse.............29

Abb. 3-3: Der stabile LEF-1 Knockdown in BL2-Zellen hat keinen Einfluss auf die

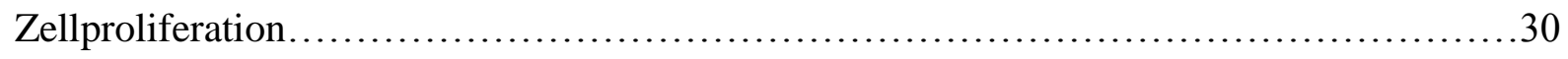

Abb. 3-4: Lymphome mit reduzierter LEF1-Expression sind durch eine geringere Tumorfläche

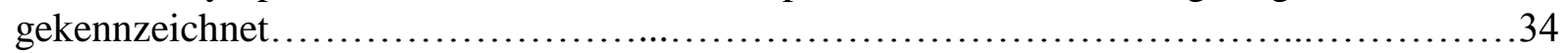

Abb. 3-5: Darstellung repräsentativer Tumoren der parentalen BL2-Zelllinie und der Kontrollzelllinie BL-2 pGIPZ ctrl 1 im Hellfeld..................................... 36

Abb. 3-6: Darstellung eines Tumors jeder Zelllinie im Hellfeld..............................37

Abb. 3-7: Fluoreszenzmikroskopische Aufnahmen LEF1-aberranter und LEF1-defizienter Tumorrändern zeigen lymphogene Gefäßmigration................................. 38

Abb. 3-8: CAM-Lymphom...................................................... 39

Abb. 3-9: HE-Schnitte der CAM-Tumoren........................................40

Abb. 3-10: HE-Schnitt eines CAM-Tumors der parentalen BL2-Zelllinie..................40

Abb. 3-11: HE-Schnitte der CAM-Tumoren...........................................41

Abb. 3-12: LEF1-defiziente Lymphome zeigen gehemmte Infiltration der CAM.............42 


\section{Tabellenverzeichnis}

Tab. 1-1: Klassifikation maligner Lymphome nach Ann-Arbor.............................

Tab. 2-1: verwendete Geräte..................................................... 10

Tab. 2-2: verwendete Verbrauchsmaterialien........................................... 11

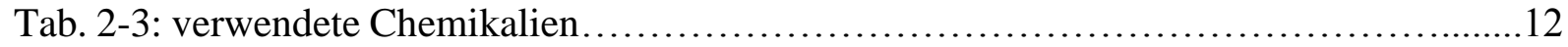

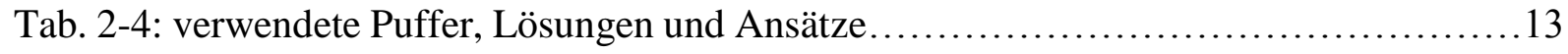

Tab. 2-5: verwendete Antikörper.................................................. 16

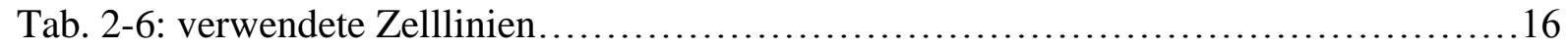

Tab. 2-7: verwendete Software................................................... 16

Tab. 2-8: etablierte BL2-Zelllinien................................................. 18

Tab. 3-1: Übersicht aller geernteter Tumoren der 3 CAM-Assays............................ 31

Tab. 3-2: Mittelwerte der CAM-Tumorflächen.........................................32

Tab. 3-3: Signifikanzen zwischen den jeweiligen Xenograft-Lymphom-Tumorflächen........35 
Ahn T, Yim SK, Choi HI, Yun CH (2001): Polyacrylamide gel electrophoresis without a stacking gel: use of amino acids as electrolytes. Anal Biochem 291, 300-303

Ausprunk DH, Knighton DR, Folkman J (1974): Differentiation of vascular endothelium in the chick chorioallantois: a structural and autoradiographic study. Dev Biol $\underline{38}, 237-248$

Baenkler HW, Fritze D, Füeß1 HS: Innere Medizin. Duale Reihe. Thieme, Stuttgart 2008

Becker J, Covelo-Fernandez A, von Bonin F, Kube D, Wilting J (2012): Specific tumorstroma interactions of EBV-positive Burkitt's lymphoma cells in the chick chorioallantoic membrane. Vasc Cell.; $\underline{4(1)}, 3$

Bertrand S, Berger R, Philip T, Bernheim A, Bryon PA, Bertoglio J, Doré JF, Brunat-Mentigny M, Lenoir GM (1981): Variant translocation in a non endemic case of Burkitt's lymphoma: $\mathrm{t}(8 ; 22)$ in an Epstein--Barr virus negative tumour and in a derived cell line. Eur J Cancer 17: 577-584

Blank U, Karlsson G, Karlsson S (2008): Signaling pathways governing stem-cell fate. Blood 111, 492-503.

Bradford MM (1976): A rapid and sensitive method for the quantitation of microgram quantities of protein utilizing the principle of protein-dye binding. Anal Biochem 72: 248-254.

Burkitt D (1958): A sarcoma involving the jaws in African children. Br J Surg 46: 218-223.

Dempke W: Lehrbuch Hämato-Onkologie: Hämatologie - Onkologie - Hämostaseologie (Bern: Hans Huber) 2008.

Deryugina EI, Quigley JP (2008a): CHAPTER TWO: Chick Embryo Chorioallantoic Membrane Models to Quantify Angiogenesis Induced by Inflammatory and Tumor Cells or Purified Effector Molecules. Methods Enzymol 444: 21-41.

Deryugina EI, Quigley JP (2008b): Chick embryo chorioallantoic membrane model systems to study and visualize human tumor cell metastasis. Histochem Cell Biol 130: 1119-1130 .

Dürkop H, Foss H, Stein H (2011): 2008-WHO-Klassifikation der malignen Lymphome im Jahr 2011. Onkol 2011 769-789.

Fortune JE, Cushman RA, Wahl CM, Kito S (2000): The primordial to primary follicle transition. Mol Cell Endocrinol 163: 53-60.

Gao X, Wen J, Zhang L, Li X, Ning Y, Meng A, Chen Y-G (2008): Dapper1 is a nucleocytoplasmic shuttling protein that negatively modulates Wnt signaling in the nucleus. J Biol Chem 283: 35679-35688 doi:10.1074/jbc.M804088200.

Gao X, Mi Y, Ma Y, Jin W (2014): LEF1 regulates glioblastoma cell proliferation, migration, invasion, and cancer stem-like cell self-renewal. Tumour Biol.;35(11):11505-11.

Gerok W, Huber C, Meinertz T, Zeidler H: Die innere Medizin: Referenzwerk für den Facharzt, New York: Schattauer, Stuttgart 2007.

Hanahan D, Weinberg RA (2000): The hallmarks of cancer. Cell 100(1): 57-70

Herold G: Innere Medizin. Gerd Herold (Verlag), Köln 2014.

Hoelzer D, Ludwig W-D, Thiel E, (1996): Improved outcome in adult B-cell acute lymphoblastic leukemia. Blood.;87:495-508. 
Hoeppner LH, Secreto FJ, Razidlo DF, Whitney TJ, Westendorf JJ (2011): Lef1DeltaN binds beta-catenin and increases osteoblast activity and trabecular bone mass. J Biol Chem 286: 10950-10959.

Hummel M, Bentink S, Berger H, Klapper W, Wessendorf S, Barth TFE, Bernd H-W, Cogliatti SB, Dierlamm J, Feller AC (2006): A Biologic Definition of Burkitt's Lymphoma from Transcriptional and Genomic Profiling. N Engl J Med 354: 2419-2430.

Husmann G, Kaatsch P, Katalinic A, Bertz J, Haberland J, Kraywinkel K, Wolf U (2010): Krebs in Deutschland 2005/2006. Häufigkeiten und Trends. 7. Ausgabe; Robert-Koch-Institut (Hrsg.) und die Gesellschaft der epidemiologischen Krebsregister in Deutschland e.V. (Hrsg.), Berlin

Klein U, Dalla-Favera R (2008): Germinal centres: role in B-cell physiology and malignancy. Nat Rev Immunol 8: 22-33.

Kompetenznetz Maligne Lymphome (2014) http://www.lymphome.de/InfoLymphome/NonHodgkinLymphome/Einteilung.jsp. [Zugriff am 12.10.2015]

Laemmli UK (1970): Cleavage of structural proteins during the assembly of the head of bacteriophage T4. Nature 227: 680-685.

Liang J, Li Y, Daniels G, Sfanos K, De Marzo A, Wei J, Li X, Cheng W, Wang J, Zhong X, Melamed J, Zhao J, Lee P (2015): LEF1 Targeting EMT in Prostate Cancer Invasion is Regulated by miR-34a. Mol Cancer Res.

Lu D, Zhao Y, Tawatao R, Cottam HB, Sen M, Leoni LM, Kipps TJ,Corr M, Carson DA (2004): Activation of the Wnt signaling pathway in chronic lymphocytic leukemia. Proc Natl Acad Sci U S A, 101:3118e3123.

Maruo S, Nanbo A, Takada K (2001): Replacement of the Epstein-Barr Virus Plasmid with the EBER Plasmid in Burkitt's Lymphoma Cells. J Virol 75: 9977-9982.

Mullighan CG, Goorha S, Radtke I, Miller CB, Coustan-Smith E,Dalton JD, Girtman K, Mathew S, Ma J, Pounds SB, Su X, Pui CH,Relling MV, Evans WE, Shurtleff SA, Downing JR (2007): Genome-wide analysis of genetic alterations in acute lymphoblastic leukaemia.Nature, 446:758e764

Murphy JB (1913): Transplantability of tissues to the embryo of foreign species. J Exp Med 17: $482-493$.

Petersson M, Reuter K, Brylka H, Kraus A, Schettina P, Niemann C (2015): Interfering with stem cell-specific gatekeeper functions controls tumour initiation and malignant progression of skin tumours. Nat Commun.;6:5874.

Pfreundschuh M, Trümper L, Kloess M, Schmits R, Feller AC, Rudolph C, Reiser M, Hossfeld DK, Metzner B, Hasenclever D (2004 a): Two-weekly or 3-weekly CHOP chemotherapy with or without etoposide for the treatment of young patients with goodprognosis (normal LDH) aggressive lymphomas: results of the NHL-B1 trial of the DSHNHL. Blood 104(3): 626-33 
Pfreundschuh M, Trümper L, Kloess M, Schmits R, Feller AC, Rübe C, Rudolph C, Reiser M, Hossfeld DK, Eimermacher H (2004 b): Two-weekly or 3-weekly CHOP chemotherapy with or without etoposide for the treatment of elderly patients with aggressive lymphomas: results of the NHL-B2 trial of the DSHNHL. Blood 104(3): 634-41

Phng LK, Potente M, Leslie JD, Babbage J, Nyqvist D, Lobov I, Ondr JK, Rao S, Lang RA, Thurston G, Gerhardt H (2009): Nrarp coordinates endothelial Notch and Wnt signaling to control vessel density in angiogenesis. Dev Cell. 70-82.

Planutiene M, Planutis K, Holcombe RF (2011): Lymphoid enhancer-binding factor 1, a representative of vertebrate-specific Lef1/Tcf1 sub-family, is a Wnt-beta-catenin pathway target gene in human endothelial cells which regulates matrix metalloproteinase2 expression and promotes endothelial cell invasion. Vasc Cell.;3:28.

Rassow J, Hauser K, Netzker R, Deutzmann R: Biochemie (Duale Reihe), Thieme, Stuttgart 2012.

Rattis FM, Voermans C, Reya T (2004): Wnt signaling in the stem cell niche. Curr. Opin. Hematol. 11, 88-94.

Reya T, O'Riordan M, Okamura R, Devaney E, Willert K, Nusse R, Grosschedl R (2000): Wnt signaling regulates $\mathrm{B}$ lymphocyte proliferation through a LEF-1 dependent mechanism. :

Ribatti D (2010a): The Chick Embryo Chorioallantoic Membrane as an In Vivo Assay to Study Antiangiogenesis. Pharmaceuticals 3: 482-513.

Ribatti D: The chick embryo chorioallantoic membrane in the study of angiogenesis and metastasis, Springer, Dordrecht, 2010b

Romanoff AL: The avian embryo: structural and functional development, Macmillan, 1960.

Shang D, Bi R, Han T, Wang D, Tian Y, Liu Y (2014): Expression and proliferation- promoting role of lymphoid enhancer-binding factor 1 in human clear cell renal carcinoma. Cancer Invest.;32(7):368-74.

Shelton DN, Fornalik H, Neff T, Park SY, Bender D, DeGeest K, Liu X, Xie W, Meyerholz DK, Engelhardt JF, Goodheart MJ (2012): The role of LEF1 in endometrial gland formation and carcinogenesis. PloS One 7.

Staal FJ, Luis TC, Tiemessen MM (2008): WNT signalling in the immune system: wNT is spreading its wings. Nat Rev Immunol, 8: 581e593

Stein PDH, Hummel M (2007): Burkitt- und Burkitt-ähnliche Lymphome. Pathol 28: 41-45.

Tan CW, Gardiner BS, Hirokawa Y, Smith DW, Burgess AW (2014): Analysis of Wnt signaling $\beta$-catenin spatial dynamics in HEK293T cells. BMC Systems Biology, 8:44.

Tiemann M, Trümper L (2001): Pathologie, Biologie und Klassifikation maligner NonHodgkin-Lymphome. Onkol 7: 940-959.

Travis A, Amsterdam A, Belanger C, Grosschedl R (1991): LEF-1, a gene encoding a lymphoid-specific protein with an HMG domain, regulates T-cell receptor alpha enhancer function [corrected]. Genes Dev 5: 880-894.

Van Den Berg DJ, Sharma AK, Bruno E, Hoffman (1998): R. Role of members of the Wnt gene family in human hematopoiesis. Blood 92, 3189-3202. 
Walther N, Ulrich A, Vockerodt M, von Bonin F, Klapper W, Meyer K, Eberth S, Pukrop T, Spang R, Trümper L (2013): Aberrant Lymphocyte Enhancer-Binding Factor 1 Expression Is Characteristic for Sporadic Burkitt's Lymphoma. Am J Pathol 182: 10921098.

Weber WT, Mausner R (1977): Migration patterns of avian embryonic bone marrow cells and their differentiation to functional T and B cells. Adv Exp Med Biol 88: 47-59.

World Health Organisation (2008): WHO-Klassifikation von lymphatischen und hämatopoetischen Neoplasien

Wilting J, Birkenhäger R, Eichmann A, Kurz H, Martiny-Baron G, Marmé D, McCarthy JE, Christ B, Weich HA (1996): VEGF121 induces proliferation of vascular endothelial cells and expression of flk-1 without affecting lymphatic vessels of chorioallantoic membrane. Dev Biol 176: 76-85. 
Ausmessungen der einzelnen CAM-Assay-Runden:

\begin{tabular}{|c|c|c|c|c|c|}
\hline & \multicolumn{5}{|c|}{ Tumorflächen in $\mathrm{cm}^{2}$} \\
\hline Zelllinie & BL-2 & BL-2 scrb 1 & BL-2 scrb 2 & BL-2 shA & BL-2 shE \\
\hline$\overline{\text { Runde } 0}$ & 0,574 & & & & \\
\hline Runde 0 & 0,489 & & & & \\
\hline Runde 0 & 0,156 & & & & \\
\hline Runde 0 & 0,344 & & & & \\
\hline Runde 1 & & 0.466 & 0,510 & 0,273 & 0,239 \\
\hline Runde 1 & & 0.457 & 0,714 & 0,125 & 0,399 \\
\hline Runde 1 & & 0.182 & 0,340 & 0,333 & 0,513 \\
\hline Runde 1 & & 0.542 & 0,551 & 0,216 & 0,168 \\
\hline Runde 1 & & 0.502 & 0,596 & 0,205 & 0,168 \\
\hline Runde 1 & & 0.759 & 0,496 & 0,328 & 0,172 \\
\hline Runde 1 & & 0.471 & 0,548 & 0,512 & 0,482 \\
\hline Runde 1 & & 0.590 & 0,202 & 0,261 & 0,361 \\
\hline Runde 1 & & 0.446 & & 0,26 & 0,161 \\
\hline Runde 1 & & 0.329 & & 0,341 & \\
\hline Runde 1 & & & & 0,144 & \\
\hline Runde 2 & 0,266 & 0,188 & 0.078 & 0,220 & 0,250 \\
\hline Runde 2 & 0,311 & 0,444 & 0,244 & 0,125 & 0,183 \\
\hline Runde 2 & 0,435 & 0,201 & 0,253 & 0,057 & 0,269 \\
\hline Runde 2 & 0,131 & 0,374 & 0,290 & 0,178 & 0,302 \\
\hline Runde 2 & & 0,412 & 0,307 & 0,322 & 0,231 \\
\hline Runde 2 & & 0,418 & 0,456 & 0,159 & 0,296 \\
\hline Runde 2 & & & 0,318 & 0,041 & 0,177 \\
\hline Runde 2 & & & 0,129 & 0,262 & 0,250 \\
\hline Runde 2 & & & & & 0,307 \\
\hline Runde 3 & 0,382 & 0,188 & 0,388 & 0,220 & 0,313 \\
\hline Runde 3 & & 0,444 & 0,232 & 0,125 & 0,309 \\
\hline Runde 3 & & 0,201 & 0,391 & 0,057 & 0,401 \\
\hline Runde 3 & & 0,374 & 0,289 & 0,178 & 0,344 \\
\hline Runde 3 & & 0,412 & 0,423 & 0,322 & 0,289 \\
\hline Runde 3 & & 0,418 & 0,338 & 0,159 & 0,441 \\
\hline Runde 3 & & 0,188 & 0,453 & 0,041 & 0,264 \\
\hline Runde 3 & & 0,444 & 0,646 & 0,262 & 0,263 \\
\hline Runde 3 & & & 0,380 & 0,220 & 0,306 \\
\hline Runde 3 & & & 0,434 & 0,125 & 0,456 \\
\hline $\begin{array}{l}\text { Mittelwert } \\
\left(\mathrm{cm}^{2}\right)\end{array}$ & 0,3440 & 0,4200 & $\mathbf{0 , 3 8 4 0}$ & 0,2469 & 0,2905 \\
\hline
\end{tabular}




\section{$11 \quad$ Versicherung}

Ich versichere hiermit, dass ich die vorliegende Arbeit mit dem Thema:

\section{Einfluss von LEF1 auf das Tumorwachstum im Burkitt-Lymphom Xenograft-Modell}

selbstständig verfasst und keine anderen Hilfsmittel als die angegebenen benutzt habe. Die Stellen, die anderen Werken dem Wortlaut oder dem Sinn nach entnommen sind, habe ich in jedem einzelnen Fall durch Angabe der Quelle kenntlich gemacht. Ich erkläre hiermit weiterhin, dass ich meine wissenschaftlichen Arbeiten nach den Prinzipien der guten wissenschaftlichen Praxis gemäß der gültigen „Richtlinien der Georg-August-Universität Göttingen zur Sicherung guter wissenschaftlicher Praxis“ angefertigt habe.

Göttingen, den

(Stefan Ueberdiek) 


\section{Danksagung}

Ganz herzlich möchte ich mich bei denen bedanken, ohne die die Anfertigung und Vollendung dieser Arbeit nicht möglich gewesen wäre:

Herrn Prof. Dr. med. Lorenz Trümper für die Möglichkeit, diese Arbeit in seiner Abteilung durchführen zu dürfen

Herrn Prof. Dr. rer. Nat. Dieter Kube für die Chance, diese Arbeit in seiner Forschergruppe zu absolvieren sowie für die Unterstützung in zahlreichen Gesprächen

Frau Dr. rer. nat. Sonja Eberth für die mütterliche Hingabe bei der Einarbeitung in diese Arbeit sowie der Bereitstellung der stabil transduzierten BL-Zelllinien

Pia Wilming für die Unterstützung bei der Arbeit im Labor sowie bei dem Verfassen dieser Arbeit

Frederike von Bonin für die stoische Ruhe bei meiner Einarbeitung im Labor sowie der Mithilfe bei vielen Teilarbeiten zu meiner Arbeit (insbesondere für die Fensterung gefühlter unendlicher Hühnereier)

Allen weiteren Mitgliedern der AG Kube, mit denen ich meine ersten Laborerfahrungen teilen durfte und in der glücklicherweise stets eine angenehme und kollegiale Arbeitsatmosphäre herrschte: M Sc. Franziska Linke, M. Sc. Maren Schmidt, Neele Walther, Susanne Hengst, Dr. rer. nat. Christina Heemann, M. Sc. Natalie Klytta, Dr. rer. nat. Elisabeth Hand, M. Sc. Rosemol George,

Den Mitgliedern der AG Wilting des Zentrums Anatomie in Göttingen für die zeitintensive Unterstützung bei den CAM-Assays sowie bei der histologischen Aufarbeitung der CAMTumoren: Prof. Dr. rer. nat. Jörg Wilting, Dr. rer. nat. Jürgen Becker, M. Sc. Marcel Klingenberg, Sonja Schwoch, Christina Zelent und dem sehr unterhaltsamen FC-Bayern-Fan Berti Manshausen 


\section{Lebenslauf}

Ich, Stefan Ueberdiek, wurde am 31.08.1988 in Dresden geboren. Von 1995 bis 1999 besuchte ich die Grundschule Bünde-Mitte. Ab 1999 bis 2005 führte ich meine Schullaufbahn auf dem Gymnasium am Markt in Bünde fort. Meinen Abiturabschluss absolvierte ich am katholischen Privatgymnasium Arnold-Janssen des Bistums Münster, das ich von 2006 bis 2008 besuchte. Im Wintersemester 2008/2009 immatrikulierte ich mich zum Studium der Humanmedizin an der Georg-August-Universität, Göttingen, um dort im September 2010 mein 1. Staatsexamen abzulegen. Im Frühjahr 2014 bestand ich den schriftlichen Teil des 2. Staatsexamens. Ab Mai 2014 befand ich mich im Praktischen Jahr des Humanmedizinstudiums, welches ich für das Innere Medizin-Tertial im Universitätsklinikum in Göttingen in der Abteilung Hämatologie/Onkologie sowie der Abteilung Nephrologie/Rheumatologie absolviert habe. Meinen chirurgischen Teil des Praktischen Jahres habe ich zum einen im Department of Cardiothoracic Surgery des Groote Schuur Hospitals in Kapstadt und zum anderen in der Abteilung für Allgemein-, Viszeral - und Onkologische Chirurgie des Klinikums Bremen-Mitte absolviert. Mein Wahltertial übte ich in der Urologie des Universitätsklinikums HamburgEppendorf aus. Am 10. Juni 2015 habe ich mein Medizinstudium mit dem Dritten Abschnitt der Ärztlichen Prüfung an der Georg-August-Universität beendet. Derzeitig arbeite ich als Assistenzarzt in der Weiterbildung zum Urologen am Universitätsklinikum des Saarlandes in Homburg/Saar. Meinen wissenschaftlichen Schwerpunkt möchte ich in Zukunft auf die Erarbeitung neuer Verständnisse von Metastasierungsvorgängen urologischer Neoplasien legen. 